\title{
ARPP-16 Is a Striatal-Enriched Inhibitor of Protein Phosphatase 2A Regulated by Microtubule-Associated Serine/Threonine Kinase 3 (Mast 3 Kinase)
}

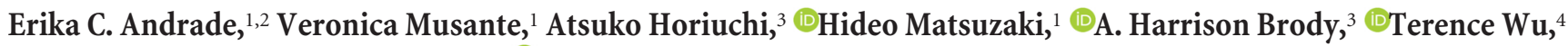 \\ Paul Greengard, ${ }^{3}$ Jane R. Taylor, ${ }^{1}$ and ${ }^{\circledR}$ Angus C. Nairn ${ }^{1}$ \\ ${ }^{1}$ Department of Psychiatry, Yale University School of Medicine, New Haven, Connecticut 06508, ${ }^{2}$ Department of Pharmacology, Yale University School of \\ Medicine, New Haven, Connecticut 06520, ${ }^{3}$ Laboratory of Molecular and Cellular Neuroscience, Rockefeller University, New York, New York 10065, and \\ ${ }^{4}$ Keck Biotechnology Resource Center, Yale University, New Haven, Connecticut 06511
}

ARPP-16 (cAMP-regulated phospho-protein of molecular weight $16 \mathrm{kDa}$ ) is one of several small acid-soluble proteins highly expressed in medium spiny neurons of striatum that are phosphorylated in response to dopamine acting via D1 receptor/protein kinase A (PKA) signaling. We show here that ARPP-16 is also phosphorylated in vitro and in vivo by microtubule-associated serine/threonine kinase 3 (MAST3 kinase), an enzyme of previously unknown function that is enriched in striatum. We find that ARPP-16 interacts directly with the scaffolding A subunit of the serine/threonine protein phosphatase, PP2A, and that phosphorylation of ARPP-16 at Ser46 by MAST3 kinase converts the protein into a selective inhibitor of B55 $\alpha$-and B56 $\delta$-containing heterotrimeric forms of PP2A. Ser46 of ARPP-16 is phosphorylated to a high basal stoichiometry in striatum, suggestive of basal inhibition of PP2A in striatal neurons. In support of this hypothesis, conditional knock-out of ARPP-16 in CaMKII $\alpha$ ::cre/floxed ARPP-16/19 mice results in dephosphorylation of a subset of PP2A substrates including phospho-Thr75-DARPP-32, phospho-T308-Akt, and phospho-T202/Y204-ERK. Conditional knock-out of ARPP-16/19 is associated with increased motivation measured on a progressive ratio schedule of food reinforcement, yet an attenuated locomotor response to acute cocaine. Our previous studies have shown that ARPP-16 is phosphorylated at Ser88 by PKA. Activation of PKA in striatal slices leads to phosphorylation of Ser88, and this is accompanied by marked dephosphorylation of Ser46. Together, these studies suggest that phospho-Ser46-ARPP-16 acts to basally control PP2A in striatal medium spiny neurons but that dopamine acting via PKA inactivates ARPP-16 leading to selective potentiation of PP2A signaling.

Key words: cocaine; dopamine; medium spiny neuron; motivation; protein kinase A

\section{Significance Statement}

We describe a novel mechanism of signal transduction enriched in medium spiny neurons of striatum that likely mediates effects of the neurotransmitter dopamine acting on these cells. We find that the protein ARPP-16, which is highly expressed in striatal medium spiny neurons, acts as a selective inhibitor of certain forms of the serine/threonine protein phosphatase, PP2A, when phosphorylated by the kinase, MAST3. Under basal conditions, ARPP-16 is phosphorylated by MAST3 to a very high stoichiometry. However, the actions of MAST3 are antagonized by dopamine and cAMP-regulated signaling leading to disinhibition of ARPP-16 and increased PP2A action.

\section{Introduction}

Our previous studies have identified a family of phospho-protein substrates for cAMP-dependent protein kinase (protein kinase A

Received Dec. 21, 2015; revised Jan. 20, 2017; accepted Jan. 25, 2017

Author contributions: E.C.A., V.M., J.R.T., and A.C.N. designed research; E.C.A., V.M., A.H., H.M., A.H.B., and T.W. performed research; P.G. contributed unpublished reagents/analytic tools; E.C.A., V.M., A.H.B., T.W., J.R.T., and A.C.N. analyzed data; E.C.A., V.M., P.G., J.R.T., and A.C.N. wrote the paper.

This work was supported by National Institutes of Health DA10044 to A.C.N. and P.G., DA11717 to J.R.T., and NS091336 to A.C.N. and V.M. Proteomic analysis was supported by the Yale/National Institute on Drug Abuse Neuroproteomics Center (DA018343). This work was also supported by the State of Connecticut, Department of
[PKA]) in striatal medium spiny neurons (MSNs) (Walaas et al., 1983a, b). These include DARPP-32 (dopamine and cAMPregulated phospho-protein of apparent molecular weight $32 \mathrm{kDa}$ ),

Mental Health and Addiction Services. We thank Meika Sanderson for assistance; Dr. Fanyan Wei, Dr. Shannon Gourley, Dr. Dilja Krueger, and Dr. Rob Sears for helpful advice; and Dr. Ewa Folta-Stogniew for technical help The authors declare no competing financial interests.

E.C. Andrade's present address: Laboratory of Molecular Biology, Rockefeller University, New York, NY 10065. Correspondence should be addressed to Dr. Angus C. Nairn, Department of Psychiatry, Yale University School of Medicine, New Haven, CT 06508. E-mail: angus.nairn@yale.edu. DOI:10.1523/JNEUROSCI.4559-15.2017

Copyright $\odot 2017$ the authors $\quad 0270-6474 / 17 / 372709-14 \$ 15.00 / 0$ 
ARPP-21 (now termed RCS for regulator of calmodulin signaling), ARPP-16, and ARPP-90 (now known to be RAP1GAP) (Walaas et al., 1983a; Hemmings et al., 1984a, b; Hemmings and Greengard, 1989; Horiuchi et al., 1990; McAvoy et al., 2009). The roles of DARPP-32 and RCS have been well documented; DARPP-32, when phosphorylated by PKA, acts as a potent inhibitor of protein phosphatase-1 (PP1) (Hemmings et al., 1984a), whereas RCS, when phosphorylated by PKA, acts to sequester calmodulin and to inhibit calmodulin signaling, including the regulation of PP2B (also known as calcineurin) (Rakhilin et al., 2004). Extensive studies have indicated that DARPP-32 and RCS play critical roles in mediating the effects of dopamine in the brain (Greengard et al., 1999; Rakhilin et al., 2004; Walaas et al., 2011; Yger and Girault, 2011; Davis et al., 2012). However, little is known about the role of ARPP-16 in the striatum.

ARPP-16 is closely related to ARPP-19, an alternatively spliced variant that contains an additional 16 amino acids at the $\mathrm{N}$ terminus. ARPP-16/19 are also related to $\alpha$-endosulfine (ENSA or ARPP19e), a distinct gene product that is highly conserved within the common region of ARPP-16/19 but contains an N-terminal region distinct from that of ARPP-19 (Horiuchi et al., 1990; Dulubova et al., 2001). ARPP-16 is highly expressed in MSNs in the dorsal striatum, nucleus accumbens, and also to a lesser extent in amygdala and frontal cortex (Girault et al., 1990; Brené et al., 1994). In contrast, ARPP-19 is expressed in non-neuronal cells. ENSA is widely distributed in brain and represents most of the $19 \mathrm{kDa}$ form of the ARPP-16/ENSA proteins in striatum (Dulubova et al., 2001).

In the current study, we have used proteomic methods to demonstrate a direct interaction between ARPP-16 and the A subunit of the serine/threonine phosphatase, PP2A. Moreover, we find that ARPP-16 is phosphorylated at Ser46 by MAST3 kinase, an enzyme of previously unknown function, and that phosphorylation converts ARPP-16 into a selective inhibitor of heterotrimeric forms of PP2A (catalytic C subunit, plus core A subunit, and accessory B subunits). Biochemical experiments and behavioral studies of mice lacking ARPP-16 in forebrain suggest that phospho-Ser46-ARPP-16 acts to basally inhibit PP2A activity toward selected substrates and that this can be attenuated via cAMP-mediated dephosphorylation of Ser46. These results complement recent studies that have identified a role for ARPP19 , ENSA and the Greatwall ( $\mathrm{Gwl}$ ) kinase, as regulators of PP2A during mitosis (Gharbi-Ayachi et al., 2010; Mochida et al., 2010) but show that in striatal neurons this PP2A regulatory system is regulated and used in a distinct manner.

\section{Materials and Methods}

Materials. pET28-ARPP-16, pET28-ARPP-19, and pGEXKG-PP2A-A were prepared using standard procedures. Truncation mutants of the PP2A A-subunit were created using a pGEXKG-PP2A-A construct.

Antibodies used for these studies include the following: anti-rabbit total ARPP-16/19/e (1:1000 G153) (Horiuchi et al., 1990), anti-rabbit pS46/62 on ARPP-16/19/e (1:1000 RU1102, generated as described below), anti-rat PP2A-A antibody (1:1000 Covance), anti-mouse PP2A-C (1:2000) (catalog \#05-421 RRID:AB_309726) and anti-HA antibody (1: 1000) (catalog \#05-904 RRID:AB_11213751) (both from Millipore), monoclonal RCS (1:5000 6A) (Ouimet et al., 1989), monoclonal total DARPP-32 (1:5000 5a) (Ouimet et al., 1984), anti-rabbit pT75 on DARPP-32 (1:500 RU911), anti-rabbit pT34 on DARPP-32 (1:1000 cc500) (Stipanovich et al., 2008), total Akt (catalog \#2966L RRID: AB_823417), pT308 on Akt (catalog \#4056 also 4056S, 4056L RRID: AB_331163) (1:1000), monoclonal total ERK1/2 (catalog \#9107S RRID:AB_10695739) (1:1000), anti-rabbit pT202/Y204 on ERK1/2 (catalog \#4370 RRID:AB_2315112) (1:2000), and total Tau (tau46 1:1000) (catalog \#4019S RRID:AB_10695394) (all obtained from Cell Signaling
Technology), p396 on Tau (1:1000 Invitrogen), anti-rabbit total GluR1 (1:1000, Millipore Bioscience Research Reagents), anti-rabbit p845 on GluR1 (1:1000, PhosphoSolutions), total elongation factor-2 (EF2) and phospho EF2 (1:1000 G118 and 1:1000 cc81) (Marin et al., 1997). Cocaine- $\mathrm{HCl}$ was provided by the National Institute on Drug Abuse.

The RU1102 antibody was generated according to methods developed and optimized in our previous studies (Nairn et al., 1982; Czernik et al., 1991). A phospho-peptide encompassing residues 41-50 of ARPP-16 (QKYFDpSGDYN) was used to generate polyclonal rabbit antibodies. The phospho-antibody fraction was selectively enriched by serial affinity chromatography on immobilized dephospho- and phospho-peptide columns. The specificity was confirmed by immunoblotting using dephospho- and phospho-Ser46 standards (see Fig. 2) and by analysis of striatal tissue from wild-type (WT) and ARPP-16 knock-out mice (data not shown).

Expression of recombinant proteins. 6xHis-ARPP-16 and 6xHisARPP-19 proteins were overexpressed in BL21 (DE3) cells, lysed using a French pressure cell press at 1000 psi (Thermo Spectronic) in binding buffer $(300 \mathrm{~mm} \mathrm{NaCl}, 50 \mathrm{~mm}$ potassium phosphate, $10 \mathrm{~mm}$ imidazole, $\mathrm{pH}$ 8.0) and immobilized onto Profinity IMAC $\mathrm{Ni}^{2+}$ charged resin (Bio$\mathrm{Rad})$. The resin was then washed 3 times for 5 min each in wash buffer (300 $\mathrm{mm} \mathrm{NaCl}, 50 \mathrm{~mm}$ potassium phosphate, $20 \mathrm{~mm}$ imidazole, $\mathrm{pH} 8.0$ ), and then proteins were eluted using $10 \mathrm{ml}$ elution buffer $(300 \mathrm{mM} \mathrm{NaCl}$, $50 \mathrm{~mm}$ potassium phosphate, $250 \mathrm{~mm}$ imidazole, $\mathrm{pH} 8.0$ ), $1 \mathrm{ml}$ fractions were collected, and protein content determined using SDS-PAGE.

GST-PP2A-A and truncation mutants were overexpressed in BL21 cells, lysed using a French pressure cell press, and immobilized onto glutathione Sepharose 4 Fast Flow beads (GE Healthcare). Beads were washed 3 times with $1 \times$ PBS for 5 min each. Protein was eluted $(50 \mathrm{~mm}$ Tris- $\mathrm{HCl}, \mathrm{pH}$ 8.0, $10 \mathrm{~mm}$ glutathione), and the GST tag was cleaved off overnight at room temperature with thrombin $(\sim 2 \mathrm{U} / \mathrm{ml})$.

Size-exclusion chromatography (SEC). To ensure highly pure 6xHisARPP-16 and 6xHis-ARPP-19 as well as remove the cleaved GST tag from PP2A-A for pulldown assays, SEC was performed with assistance from the National Institute on Drug Abuse Neuroproteomics Center Biophysics Core. Proteins were separated on a Superdex 75-10/300 column (GE Healthcare) connected to a 2695 HPLC system (Waters) equilibrated with HBS (20 mм HEPES, 150 mм NaCl, 3 mм EDTA, pH 8.0). Peaks were visualized using a 2996 Photo Diode Array (Waters) and collected into $\sim 1 \mathrm{ml}$ fractions. Protein purity was determined by SDSPAGE and protein amount quantified using a BCA assay.

Identification of protein complexes using differential fluorescence gel electrophoresis (DIGE). The S2 (cytosolic) fraction from 11 adult rat striata or hippocampi were precleared with $\mathrm{Ni}^{2+}$ charged resin, followed by batchbinding to 6xHis-ARPP-16 immobilized onto $\mathrm{Ni}^{2+}$ resin in RNase-free conditions for $4 \mathrm{~h}$ at $4^{\circ} \mathrm{C}$ with shaking. Beads were washed 3 times in wash buffer $(300 \mathrm{~mm} \mathrm{NaCl}, 50 \mathrm{~mm}$ potassium phosphate, $20 \mathrm{~mm}$ imidazole, $\mathrm{pH}$ 8.0 ), and then eluted with buffer $(300 \mathrm{~mm} \mathrm{NaCl}, 50 \mathrm{~mm}$ potassium phosphate, $250 \mathrm{~mm}$ imidazole, $\mathrm{pH} 8.0)$. Striatal eluate $(50 \mu \mathrm{g})$ was labeled with Сy3, hippocampal eluate $(50 \mu \mathrm{g})$ labeled with $\mathrm{Cy} 5$, and eluate from precleared beads $(50 \mu \mathrm{g})$ labeled with Cy2 (control). DIGE was performed using an Ettan DIGE (GE Healthcare) system. Labeled samples were pooled, and isoelectric focusing was performed using a pI range of $3-10$. SDS-PAGE on a $12 \%$ gel was performed for the second dimension. Dye ratios were determined using DeCyder Software (GE Healthcare). Spots found in the striatal eluate, but not the control, were excised and subjected to in-gel tryptic digestion. Spots were identified using an Applied Biosystems 4800 MALDI-Tof/Tof mass spectrometer. The data were analyzed using the Applied Biosystems GPS Explorer software with Mascot analysis against both the NCBInr and IPI mouse databases, and a combined peptide mass fingerprint/MS/MS search was done.

In vitro pulldown assays. To determine direct interactions between ARPP-16 and PP2A-A (see Fig. 1e), 6xHis-ARPP-16 (50 $\mu \mathrm{g})$ was immobilized onto $80 \mu \mathrm{l} / \mathrm{sample}$ (of 50/50 slurry) Talon metal affinity resin (Clontech). Increasing amounts of purified PP2A-A (0, 10, 20, 40, or 80 ng) were added to the beads, and samples were incubated for $1 \mathrm{~h}$ at $4^{\circ} \mathrm{C}$ with rotation. As a control, $10 \mathrm{ng}$ PP2A-A was added to beads with no 6xHis-ARPP-16 immobilized. The beads were then washed twice with $1 \times$ TBS for 5 min each, boiled in $2 \times$ Laemmli buffer, separated and 
visualized using standard immunoblotting techniques. To control for the specificity of the ARPP-16/PP2A interaction compared with other proteins of similar size and charge (see Fig. $1 d$ ), $100 \mu \mathrm{g}$ of $6 \mathrm{xHis}-$ ARPP-16 immobilized onto $80 \mu \mathrm{l} /$ sample (of 50/50 slurry) Talon metal affinity resin was incubated with the S2 (cytosolic) fraction from 2 adult mouse striata for $3 \mathrm{~h}$ at $4^{\circ} \mathrm{C}$. After extensive washing, beads were boiled in $2 \times$ Laemmli buffer, separated by SDS-PAGE, and interactions were visualized by immunoblotting with antibodies against PP2A-A (Cell Signaling Technology), PP2A-C (Millipore), PP2B (BD Bioscience), PP1 (Epitomics) or synaptophysin (Cell Signaling Technology).

To determine which region of PP2A-A ARPP-16 and ARPP-19 could bind (see Fig. 1e), $50 \mu \mathrm{g}$ of full-length GST-PP2A-A, GST-HEAT1-9, GST-HEAT1-7, GST-HEAT3-END or GST tag control was immobilized onto $80 \mu \mathrm{l} /$ sample glutathione Sepharose 4 Fast Flow beads. Increasing concentrations of 6xHis-ARPP-16 or 6xHis-ARPP-19 in $50 \mu \mathrm{l}(0,10 \mathrm{~nm}$, $100 \mathrm{nM}$, and $1 \mu \mathrm{M}$ ) were added to the beads and incubated for $15 \mathrm{~min}$ at $4^{\circ} \mathrm{C}$ with rotation. The beads were washed twice with $1 \times$ PBS for $5 \mathrm{~min}$ with rotation at $4^{\circ} \mathrm{C}$. Proteins were eluted (50 mM Tris- $\mathrm{HCl}, \mathrm{pH}$ 8.0, 10 mM glutathione) and analyzed by SDS-PAGE followed by immunoblotting. As a control, different concentrations of 6xHis-ARPP-16 or 6xHisARPP-19 were added to beads with the GST tag immobilized to detect nonspecific binding. In addition, 6xHis-RCS, instead of 6xHis-ARPP-16, was incubated with full-length PP2A-A and truncation mutants to control for nonspecific binding.

Transfection. HEK293 (RRID:CVCL_6996) cells were cultured to $60 \%-70 \%$ confluence in 10\% FBS-DMEM. Expression plasmids ( $3 \mu \mathrm{g}$ of Flag-B56, Flag-B $\alpha$, Flag-PR72, HA-ARPP-16, or HA-MAST3) were transfected into HEK293 cells in $10 \mathrm{~cm}$ plates by using Lipofectamine 2000 (Invitrogen). Twenty-four hours after transfection, cells were lysed in a buffer containing $25 \mathrm{~mm}$ Tris, $\mathrm{pH} 7.4,150 \mathrm{~mm} \mathrm{NaCl}, 0.1 \%$ Triton $\mathrm{X}-100$, protease and phosphatase inhibitor mixtures, followed by centrifugation at $16,000 \times g$ for $10 \mathrm{~min}$. Supernatants were subjected to immunoprecipitation or immunoblotting as described below.

Immunoblotting. Cell lysates were separated by SDS-PAGE (Novex $10-20 \%$ gradient gels, Invitrogen) and transferred onto nitrocellulose membranes, $0.2 \mu \mathrm{m}$ (Bio-Rad). The membranes were blocked for $1 \mathrm{~h}$ at room temperature (5\% nonfat dry milk in PBS, $0.1 \%$ Tween 20 ) and immunoblotted overnight at $4^{\circ} \mathrm{C}$, with specific antibodies as indicated. Antibody binding was detected using IRDye 800 conjugated anti-mouse IgG (1:10,000; Rockland, catalog \#610-102-041 RRID:AB_2614830) or IRDye680 conjugated anti-rabbit IgG (1:10,000 LI-COR Bioscience, catalog \#926-68021 RRID:AB_10706309). Blots were analyzed and quantified using an Odyssey Infrared Imaging System (LI-COR Bioscience, Image Studio Lite version 3.1, RRID:SCR_013715).

ARPP-16 in vitro phosphorylation. Purified 6xHis-ARPP-16 (1 $\mu \mathrm{M})$ was incubated with immunoprecipitated MAST3 kinase in the presence of $200 \mu \mathrm{M}$ ATP (Sigma) or $1 \mathrm{~mm}$ thio- $\gamma$-ATP (Roche) in a total volume of $100 \mu \mathrm{l}$ phosphorylation assay buffer (50 mM HEPES, pH 7.4, $10 \mathrm{~mm}$ $\mathrm{MgCl}_{2}$ ) and incubated at $37^{\circ} \mathrm{C}$ for different times.

Immunoprecipitation and phosphatase assay. Flag-tagged PP2A-B subunits were expressed in HEK293 cells and cells lysed as described above. Lysates were incubated with $50 \mu \mathrm{l}$ (50\% slurry) of anti-FLAG (SigmaAldrich catalog \#F1804 RRID:AB_262044) conjugated agarose beads for $2 \mathrm{~h}$ at $4^{\circ} \mathrm{C}$. Immunocomplexes were washed 3 times in lysis buffer without phosphatase inhibitors and 2 times in PP2A reaction buffer $(50 \mathrm{~mm}$ Tris- $\mathrm{HCl}, \mathrm{pH}$ 7, $100 \mu \mathrm{M} \mathrm{CaCl}_{2}$ ). Immunocomplexes for $\mathrm{B} \alpha-$, $\mathrm{B} 56 \delta$-, or PR72-PP2A trimers or purified PP2A-AC dimer (0.01 U/ $\mu$ l, Millipore) were resuspended in $100 \mu \mathrm{l}$ of PP2A reaction buffer and incubated without or with ARPP-16 or thio- $\gamma$-phosphorylated ARPP-16 (50 nM, 100 $\mathrm{nM}, 1000 \mathrm{nM}$ ) for $10 \mathrm{~min}$ at $37^{\circ} \mathrm{C}$ in the presence of $500 \mu \mathrm{M}$ phosphopeptide (K-R-pT-I-R-R). Phosphatase activity was measured by malachite green assay kit (Millipore).

DARPP-32 in vitro phosphorylation and PP2A activity assay. Recombinant purified DARPP-32 $(200 \mu \mathrm{g})$ was phosphorylated by CDK1 at $30^{\circ} \mathrm{C}$ for $1 \mathrm{~h}$, in buffer containing $50 \mathrm{~mm}$ Tris-HCI, pH 7.1, $150 \mathrm{~mm} \mathrm{KCI}, 10 \mathrm{~mm}$ magnesium acetate, and $200 \mu \mathrm{M}\left[\gamma^{-}{ }^{32} \mathrm{P}\right]$ ATP. Proteins were precipitated in $100 \%$ trichloroacetic acid (TCA) and after extensive washing the pellet was resuspended and dialyzed in $20 \mathrm{~mm}$ Tris- $\mathrm{HCl} \mathrm{pH} \mathrm{7.6,} 5 \mathrm{~mm}$ $\beta$-mercaptoethanol. For the PP2A assay, different PP2A heterotrimers were incubated without or with ARPP-16 or thio- $\gamma$-phosphorylated ARPP-16 (200 nM) in the presence of $37.5 \mu \mathrm{M}\left[{ }^{32} \mathrm{P}\right]$-DARPP-32 for 10 min at $30^{\circ} \mathrm{C}$. Free $\left[{ }^{32} \mathrm{P}\right]$ was measured by scintillation counting (Cerenkov radiation) after precipitation of $\left[{ }^{32} \mathrm{P}\right]$-phosphoproteins with cold TCA (McAvoy and Nairn, 2010).

Animals. Mice were cared for in animal facilities located at the Connecticut Mental Health Center and operated by Charles River Laboratory staff, or in the animal facility at the Rockefeller University. Animals were maintained on a $12 \mathrm{~h}$ light/12 h dark cycle with all behavioral experiments conducted during the light cycle. Constitutive knockout of the arrp19 gene (ARPP-16/19 KO mice) is embryonic lethal (A. Horiuchi, P. Greengard, A.C. Nairn, unpublished results). We therefore generated floxed ARPP-16/19 mice, which were bred on a mixed C57BL/6/129 background. Floxed ARPP-16/19 mice were crossed with animals expressing cre recombinase under control of the CaMKII $\alpha$ promoter (CaMKII $\alpha:$ :cre) (Casanova et al., 2001). The animals were bred to homozygosity for the floxed allele and littermates either did not have cre (WT) or were hemizygous for cre (conditional KO [cKO]). PCR was used to determine mouse genotype, namely, WT or floxed ARPP-16/19, or the absence or presence of cre. Immunoblotting for the presence or absence of ARPP-16/19 in lysates from striatum and other brain regions was used to confirm genotype following completing of biochemical or behavioral studies (see Fig. 5). Male animals were used for both biochemistry as well as behavior and the breeding strategy allowed for an ARPP-16/19 cKO to WT ratio of 1:1. All animals received ad libitum normal mouse chow and water unless otherwise noted. All procedures were approved by the Yale University Animal Care and Use Committee (Institutional Animal Care and Use Committee) or the Rockefeller University Institutional Animal Care and Use Committee and (Institutional Animal Care and Use Committee) and followed the National Institutes of Health Guide for the care and use of laboratory animals.

Striatal slice preparation. Striatal slices from 6- to 8-week-old mice or 90-110 g rats were prepared as described with slight procedural modifications (Nishi et al., 1997). The brains were rapidly removed and placed in ice-cold, oxygenated Krebs- $\mathrm{HCO}_{3}$ buffer ( $124 \mathrm{~mm} \mathrm{NaCl}, 4 \mathrm{~mm} \mathrm{KCl}, 26$ mм $\mathrm{NaHCO}_{3}, 1.5 \mathrm{~mm} \mathrm{CaCl}_{2}, 1.25 \mathrm{~mm} \mathrm{KH} \mathrm{PO}_{4}, 1.5 \mathrm{~mm} \mathrm{MgSO}_{4}, 10 \mathrm{~mm}$ D-glucose, $\mathrm{pH}$ 7.4). Coronal slices $(350 \mu \mathrm{m})$ were prepared using a vibrating blade microtome (VT1000S, Leica Microsystems). Striata were dissected from the slices and then placed in a polypropylene incubation tube with $2 \mathrm{ml}$ of fresh, oxygenated Krebs- $\mathrm{HCO}_{3}$ buffer and allowed to recover for $30 \mathrm{~min}$ with constant oxygenation with $95 \% \mathrm{O}_{2} / 5 \% \mathrm{CO}_{2}$ at $30^{\circ} \mathrm{C}$ followed by another $30 \mathrm{~min}$ of recovery with adenosine deaminase added to fresh Krebs- $\mathrm{HCO}_{3}$ buffer. Slices were then treated, collected at the appropriate time point, and rapidly frozen on dry ice. Frozen striatal slices from mice or rats were sonicated in 1\% SDS containing phosphatase and protease inhibitor cocktails (Sigma-Aldrich) and quantified using a standard Pierce BCA protocol (Thermo Scientific). Total lysate (30 $\mu \mathrm{g}$ ) was loaded on $10 \%-20 \%$ gradient gels and immunoblotting was performed as described above.

The stoichiometry of phosphorylation of ARPP-16 at Ser46 in striatal extracts isolated under basal conditions was measured by immunoblotting analysis of increasing amounts of total protein $(30$ and $60 \mu \mathrm{g})$ together with a linear standard curve of recombinant $6 \mathrm{xHis}-\mathrm{ARPP}-16$ $(0.05-5 \mathrm{ng})$ phosphorylated in vitro by PKA to $\sim 1 \mathrm{~mol} / \mathrm{mol}$. Immunoblots for other proteins and phospho-proteins were performed in a similar range of protein amounts.

Progressive ratio. Acquisition of instrumental responding for food reinforcement and responding on a progressive ratio schedule was performed as described previously (Gourley et al., 2008), with some modifications. Briefly, before the start of training, male ARPP-16/19 cKOs and WT littermate controls were food-restricted to $80 \%-85 \%$ of their normal body weight. Operant chambers, $16 \times 14 \times 12.5 \mathrm{~cm}$ in size with three back-lit nose-poke apertures on one side and a magazine for food delivery on the other side, were used (Med Associates). All boxes were equipped with house lights, housed in noise attenuating chambers with white noise generators, and photocells in nose-poke apertures to measure operant responses and a food magazine, to track entry and deliver grain based food pellets ( $20 \mathrm{mg}$, Bioserv). To habituate mice to the operant boxes, as well as associate the food magazine with reinforcers, 
individual mice were placed into the operant boxes where they received a food reinforcer for every entry into the magazine for a maximum of 50 pellets or $15 \mathrm{~min}$, whichever was achieved first. The following day, individual mice were placed into the operant boxes and assigned an active nose-poke aperture, which when entered, dispensed a food reinforcer into the magazine on a VR2 schedule $(1,2$, or 3 active nose-pokes leads to reinforcement) for the duration of a $25 \mathrm{~min}$ trial. Retrieval of a food reinforcer was necessary for further reinforcement. Mice were trained to nose-poke for food reinforcement in the active aperture until stable activity was achieved ( $<15 \%$ variance over 3 consecutive days). Once mice acquired the operant task, they were placed into operant boxes to perform an escalating linear schedule of progressive ratio reinforcement. Here, mice had to respond in the active nose-poke, $1,5,9(x+4 \ldots)$ times to receive a single food reinforcer (PR4 schedule). The session was timed out when mice did not respond in the active nose-poke aperture for 5 min or the trial was terminated after $3 \mathrm{~h}$, whichever was achieved first. The active nose-poke response:reinforcement ratio was considered the breakpoint ratio and was used to measure motivation for a food reward. Two independent cohorts of mice were used for progressive ratio studies.

Locomotor activity. ARPP-16/19 cKOs and WT littermate controls were first placed into $40 \times 40 \times 30 \mathrm{~cm}$ acrylic boxes equipped with two rows of photobeams to detect vertical and horizontal movement for 60 min before cocaine exposure (Accuscan Instruments). The animals were then exposed to injection of saline or cocaine $(5,12.5,20 \mathrm{mg} / \mathrm{kg}$ i.p.), placed back into the boxes, and locomotor activity was recorded using Fusion 3.2 software for $60 \mathrm{~min}$, with measurements of distance traveled, vertical and stereotypic movement collected every 5 min. Results from this study were performed with five cohorts of animals each with ARPP16/19 cKOs and WT littermates represented.

Statistical analysis. Statistical analysis was accomplished using Statview software (SAS Institute) or Graph Pad Prism (RRID:SCR_002798) (GraphPad Software). Descriptions for statistical methods and statistical results are described within Results and figure legends.

\section{Results \\ Identification of binding partners of ARPP-16 in rodent striatum}

Preliminary studies in which GFP tagged ARPP-16 or ARPP-19 was expressed in cultured striatal neurons, or subcellular fractionation of striatal tissue, indicated that both proteins were cytosolic (data not shown). Identification of novel proteins that interacted with ARPP-16 therefore involved immobilization of recombinant 6xHisARPP-16 followed by incubation of a precleared cytosolic fraction (S2) from either rat striatum or hippocampus to identify binding partners and to also distinguish any potential striatal-specific interactions. Striatal and hippocampal lysates were incubated with beads with no His-ARPP-16 immobilized to control for nonspecific binding. Proteins isolated from striatal samples were labeled with $\mathrm{Cy} 3$, those from hippocampal samples labeled with $\mathrm{Cy} 5$, and those bound nonspecifically from control striatal and hippocampal samples pooled and labeled with Cy2. Pooled samples were then separated in two dimensions (isoelectric focusing followed by SDS-PAGE) and analyzed using 2D DIGE (Fig. 1a, hippocampal data not shown). From the DIGE analysis, 26 spots were analyzed using LC/MS/MS. From 10 proteins identified, one was found in both the striatal and hippocampal samples, but absent in the control. This protein was identified as the scaffolding A subunit of PP2A (PP2A-A) (Fig. 1a, arrow). One protein found in striatal, but not hippocampal or control samples, was identified as tubulin (Fig. $1 a$, arrowhead). These findings were replicated with an additional independent DIGE experiment (data not shown). Validation of the interaction between ARPP-16 and PP2A was performed using independent striatal samples and recombinant His-ARPP-16 (Fig. 1b). Both the PP2A-A and PP2A-C subunits were identified by immunoblotting.

PP2A consists of an active dimer of a catalytic $C$ subunit bound to a scaffolding A subunit. Various accessory B subunits also bind to the A subunit where they influence the substrate specificity of PP2A heterotrimeric isoforms (Janssens and Goris, 2001; Xing et al., 2006; Xu et al., 2006, 2008). In neurons, differences in regional and subcellular distribution of the B subunits allow for intricate regulation of PP2A activity (Strack et al., 1998). There are four B subunit gene families $\left(B, B^{\prime}, B^{\prime \prime}, B^{\prime \prime \prime}\right)$, each containing two to five members with further diversification in splice variants. Structural studies of the trimeric forms have revealed interactions between all three subunits, with the scaffolding A subunit acting as a base for $\mathrm{C}$ subunit docking while allowing for dynamic interchange of B subunits and other regulators, such as simian virus-40 (SV40) small t antigen (ST) (Xu et al., 2006, 2008; Chen et al., 2007; Cho and Xu, 2007; Cho et al., 2007). A direct interaction between 6xHis-ARPP-16 and PP2A-A was demonstrated in pull-down experiments in which immobilized HisARPP-16 was incubated with recombinant SEC-purified PP2A-A (Fig. 1c). As an additional control, we examined whether the interaction of ARPP-16 with PP2A was specific by immunoblotting for two other related protein phosphatases, PP1 and PP2B, and for synaptophysin a protein with similar surface charge to PP2A as a control for nonspecific binding to His-ARPP-16 beads. Of the proteins analyzed, only the A and C subunits of PP2A were found to interact with His-ARPP-16 (Fig. 1d).

PP2A-A consists of 15 HEAT motif repeats. Crystal structures of trimeric PP2A have shown interactions of PP2A-C with PP2A-A via HEAT repeats 11-15 (Xu et al., 2006; Cho and Xu, 2007 ) and interactions of $B$ subunits via HEAT repeats $2-8$. Crystal structures also show interactions of ST with PP2A-A via HEAT repeats 3-7 (Chen et al., 2007; Cho et al., 2007). Increasing amounts of ARPP-16, ARPP-19, or RCS (used as a control) were incubated with immobilized full-length GST-tagged PP2A-A or truncated GST-tagged mutants containing different HEAT repeats from PP2A-A. As an additional control, GST alone was also immobilized. Both ARPP-16 and ARPP-19 interacted with fulllength PP2A-A as well as with PP2A-A mutants that contained HEAT repeats 3-7 (Fig. 1e), suggesting that ARPP-16 and ARPP-19 may bind to similar regions of PP2A-A as do both B and ST subunits.

\section{Phosphorylation of Ser46 of ARPP-16 by MAST3 kinase}

Our previous studies found that PKA phosphorylates ARPP-16 at Ser88 (Ser104 in ARPP-19) near the C terminus of the protein (Dulubova et al., 2001). In unpublished work, we had also identified Ser46 (Ser62 in ARPP-19) as being phosphorylated in vitro by Rho kinase, but phosphorylation of this site was unaffected by inhibition of Rho kinase in intact cells, and the identity of the relevant kinase was unknown. However, recent studies in Xenopus oocytes have demonstrated that ARPP-19 or ENSA, when phosphorylated by Gwl on Ser62, inhibit PP2A during mitosis (Gharbi-Ayachi et al., 2010; Mochida et al., 2010). We therefore performed a BLAST sequence analysis on Gwl, identifying high homology between Gwl and the microtubule-associated serine/threonine kinase (MAST) family. The MAST-like kinase (MASTL) is the Gwl homolog in mammalian cells (Voets and Wolthuis, 2010). Among the other MAST family members, MAST3 has been shown by in situ hybridization studies to be highly enriched in the striatum (Garland et al., 2008), but to date no substrates for this kinase have been identified. For these reasons, we examined the ability of MAST3 to phosphorylate ARPP-16 (Fig. 2). Expression of MAST3 in HEK293 cells resulted in robust phosphorylation of ARPP-16 at Ser46 as measured by immunoblotting using a phospho-specific rabbit polyclonal antibody (Fig. 2a,b). Moreover, in vitro, immunoprecipitated HA-MAST3 phosphorylated Ser46 of ARPP-16 rapidly and to high stoichiometry (Fig. 2c). 
a

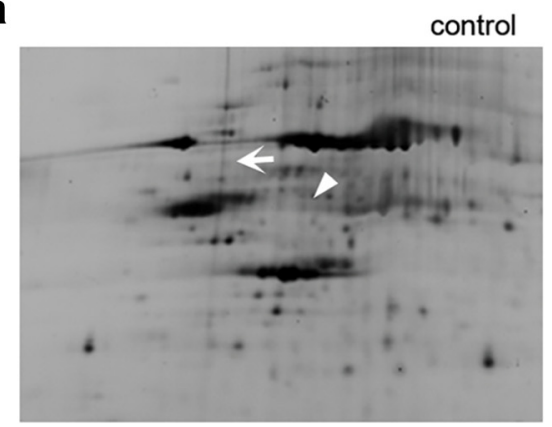

His-ARPP-16 (striatal)

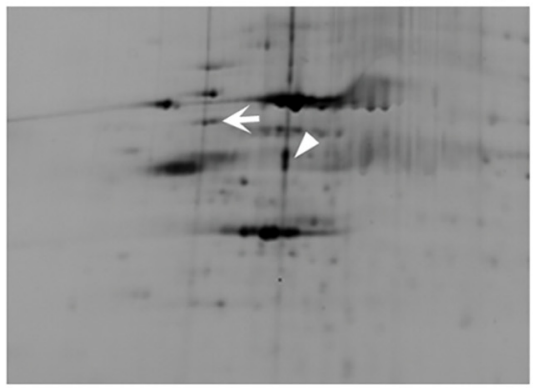

b

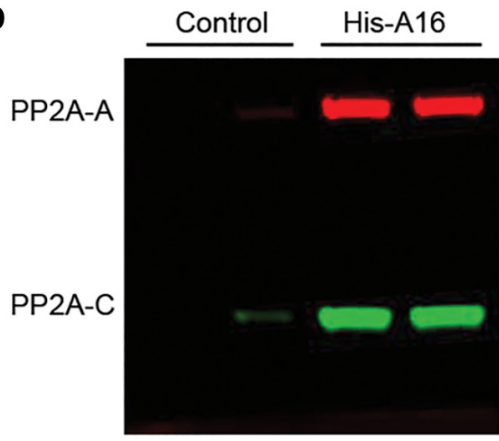

C

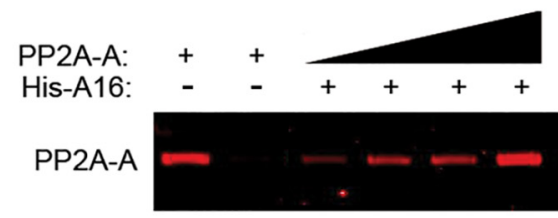

d
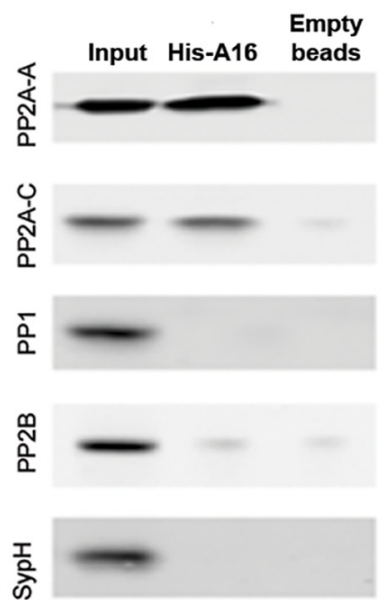

e

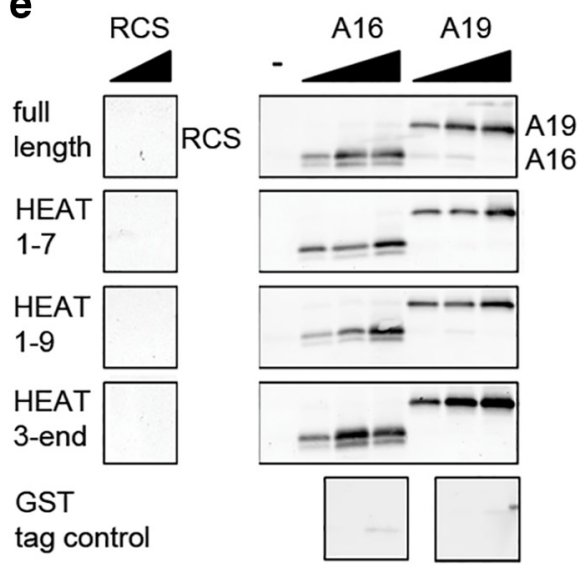

Figure 1. ARPP-16 interacts with the A subunit of PP2A. $\boldsymbol{a}$, Rat brain S2 fractions were incubated with immobilized His-ARPP16 , and then eluted proteins were separated using DIGE. The striatal sample was labeled with Cy3, whereas the control sample (nonspecific binding of striatal samples to beads with no ARPP-16) was labeled with (y2. Samples were mixed and analyzed by DIGE. White arrow indicates a spot corresponding to PP2A-A. Arrowhead indicates a spot corresponding to tubulin. $\boldsymbol{b}$, Independent striatal S2 samples were incubated with control beads (Control) or beads with immobilized His-ARPP-16 (His-A16), and bound proteins were analyzed by SDS-PAGE and immunoblotting with antibodies to PP2A-A (red) and PP2A-C (green). c, Increasing amounts of recombinant, SEC-purified PP2A-A $(10,20,40$, or $80 \mathrm{ng})$ were incubated with immobilized His-ARPP-16 (50 $\mu \mathrm{g})$ and bound protein analyzed by SDS-PAGE and immunoblotting with antibody to PP2A-A. The PP2A-A input (10 ng) is shown in lane 1, and the eluant from beads with no His-ARPP-16 that were incubated with PP2A-A (10 ng) is shown in lane 2. $\boldsymbol{d}$, Striatal lysate fraction S2 was incubated with immobilized His-ARRP-16 $(100 \mu \mathrm{g})$ or beads alone (empty beads, negative control). Eluted proteins were separated by SDS-PAGE and immunoblotted with antibody against PP2A-A, PP2A-C, PP1, PP2B, or synaptophysin. The lysate input (1\%) is showed in lane $1 ; 20 \%$ of the eluates were analyzed in lanes 2 and 3. $\boldsymbol{e}$, Full-length GST-PP2A-A, GST-tagged truncation mutants of PP2A-A that included HEAT repeats HEAT1-7, HEAT1-9, HEAT3-END, or a GST tag control (50 $\mu \mathrm{g}$ ), were immobilized onto glutathione Sepharose 4 Fast Flow beads and incubated with increasing amounts of recombinant, SEC-purified His-ARPP-16 (A16, 10, 100, or 1000 nm) or SEC-purified His-ARPP-19 (A19, 10, 100, or 1000 nm). Recombinant RCS (100 or $1000 \mathrm{~nm}$ ) was incubated with beads to determine nonspecific binding. Eluted samples were analyzed by SDS-PAGE and immunoblotted for ARPP-16, ARPP-19, or RCS.

\section{Regulation of PP2A activity by ARPP- 16 in vitro}

We next addressed the question of whether ARPP-16 phosphorylated by MAST3 was able to inhibit PP2A. However, in preliminary assays, we found that under our in vitro conditions, phospho-Ser46 was dephosphorylated by PP2A (data not shown). We therefore phosphorylated 6xHis-ARPP-16 using thio- $\gamma$-ATP, an ATP analog that produces thio-phospho-substrates characterized by slower dephosphorylation kinetics. Notably, once phosphorylated by MAST3 kinase, P- $\gamma$-Ser46-ARPP-16 was resistant to dephosphorylation by PP2A (Fig. 2d).

We first assessed the action of phosphoSer46-ARPP-16 using purified PP2A dimer containing the PP2A-A and PP2A-C subunits. PP2A dimer was incubated with increasing concentrations of dephosphoARPP-16 or phospho-Ser46-ARPP-16 phosphorylated in vitro by recombinant MAST3 (Fig. 3a). A malachite green assay, which used a synthetic peptide substrate, was initially used to assess PP2A activity. Using this substrate, a slight, but significant, inhibitory effect of dephospho-ARPP-16 on PP2A dimer activity was observed, but only at the highest concentration used (1000 nM). A similar level of inhibition was obtained using the highest concentration of phospho-Ser46-ARPP-16 (Fig. $3 a$; multivariable ANOVA with Newman-Keuls Multiple Comparison Test; $1000 \mathrm{~nm}$ dephospho-ARPP-16 vs PP2A alone, $F_{(3,8)}=13.48, p=0.0017 ; 1000$ nM phospho-ARPP-16 vs PP2A alone, $\left.F_{(3,9)}=6.906, p=0.0104\right)$.

Although there is possibly some PP2A dimer in cells, it is likely that most PP2A activity is associated with a variety of heterotrimeric forms of the protein phosphatase. PP2A specificity is strongly dependent on the regulatory $\mathrm{B}$ subunit, and our previous studies have implicated the B56 $\delta$ and PR72 heterotrimeric forms of PP2A as being highly expressed in striatum and responsible for dephosphorylation of DARPP-32 at Thr75 (Ahn et al., 2007a, b). We therefore used phospho-Thr75-DARPP-32 as a physiological substrate that would be more relevant to the function of ARPP-16 in striatum. The $\mathrm{B} 55 \alpha$ (also termed $\mathrm{B} \alpha$ ) form of PP2A has also been found to be regulated by ENSA (Mochida et al., 2010), and we included this heterotrimeric form of PP2A in the assays. The results indicated that PP2A activity was significantly inhibited only by phosphoSer46-ARPP-16 and different isoforms of PP2A exhibited varying sensitivity, with the $\mathrm{B} \alpha$ form being inhibited to the largest extent (Fig. $3 b$; multivariable ANOVA with Newman-Keuls Multiple Comparison Test; phospho-ARPP-16 vs B $55 \alpha$, phosphoARPP-16 vs dephospho-ARPP-16, $F_{(2,5)}=$ 412.6, $p=0.0001$; phospho-ARPP-16 vs B56 $\delta$, phospho-ARPP-16 vs dephospho-ARPP-16, $F_{(2,3)}=284.1$, $p=0.0004$; phospho-ARPP-16 vs PR72, phospho-ARPP-16 vs dephospho-ARPP-16, $\left.F_{(2,3)}=21.16, p=0.017\right)$. Somewhat similar results were obtained using the phospho-peptide substrate and malachite green assay method instead of ${ }^{32} \mathrm{P}$-DARPP-32 and TCA precipitation. However, the extent of inhibition by phospho-ARPP-16 
was not as great, dephospho-ARPP-16 inhibited enzyme activity, and as a consequence there was little discrimination between the effects on the different heterotrimeric forms of PP2A (data not shown). The differences observed between the effects of phospho-Ser46-ARPP-16 on PP2A activities using a native substrate compared with a synthetic peptide presumably reflect the structural basis for the interaction of ARPP-16 with the PP2A heterotrimer and polypeptide substrate.

\section{Ser46 of ARPP-16 is basally}

phosphorylated to high stoichiometry in striatal slices and is dephosphorylated in response to cAMP signaling

ARPP-16 was originally identified as being phosphorylated at Ser88 by PKA in striatal lysates (Horiuchi et al., 1990). Subsequent studies found it to be highly expressed in MSNs (Girault et al., 1990) where it can be differentially regulated by D1- and D2receptor-mediated signaling (Dulubova et al., 2001), presumably in direct and indirect pathway neurons, respectively. However, nothing is known about the regulation of the MAST kinases; but based on our studies in HEK293 cells and in vitro assays, MAST3 was basally active. Consistent with this, we measured the level of phosphorylation of Ser46 in striatal extracts isolated under basal conditions as being $\sim 0.8 \mathrm{~mol} / \mathrm{mol}$ based on the use of total ARPP-16 and phosphoSer46-ARPP-16 antibodies and phosphorylated recombinant ARPP-16 standard (data not shown). ENSA, the predominant $19 \mathrm{kDa}$ form of the protein in striatum, was also phosphorylated to a similarly high level. We next examined whether phosphorylation of Ser46-ARPP-16 (Ser62 in ENSA) was subject to regulation in striatal slices. Incubation of rat striatal slices with forskolin $(10 \mu \mathrm{M}, 10 \mathrm{~min})$, an activator of adenylyl cyclase, led to a significant decrease in phosphorylation of both ARPP-16 and ENSA at the MAST3 site (Fig. $4 a ; t_{(2)}=30.49, p<0.001$ ). These results were replicated in striatal primary cultures (data not shown). We also found that incubation of rat striatal slices with the glutamate receptor agonist NMDA ( $100 \mu \mathrm{M}$ for 5 or $15 \mathrm{~min})$ led to a significant reduction in phosphorylation of ARPP-16 at Ser46 after 15 min (Fig. $4 b$; multivariate ANOVA with Bonferroni post hoc analysis, $F_{(2,24)}=$ 5.22, $p=0.0131$ ), yet no significant difference was detected for Ser62-ENSA. Ser46-ARPP-16 is contained within a conserved motif, which also includes an adjacent tyrosine that might be phosphorylated $([\mathrm{RK}]-x(2)-[\mathrm{DE}]-x(3)-\mathrm{Y})$. Conceivably, the reduction in Ser46 phosphorylation might be secondary to increased phosphorylation of the adjacent tyrosine and interference with phosphoantibody binding. However, pan inhibition of tyrosine kinases with genistein in striatal slices did not influence the effect of forskolin on Ser46 dephosphorylation (data not shown).

ARPP-16 acts to regulate phosphorylation of selective PP2A substrates in striatal neurons

Our results indicate that ARPP-16 phosphorylated at Ser46 by MAST3 acts as an inhibitor of specific heterotrimeric forms of PP2A. Moreover, phosphorylation of Ser46 is basally high in stri- b

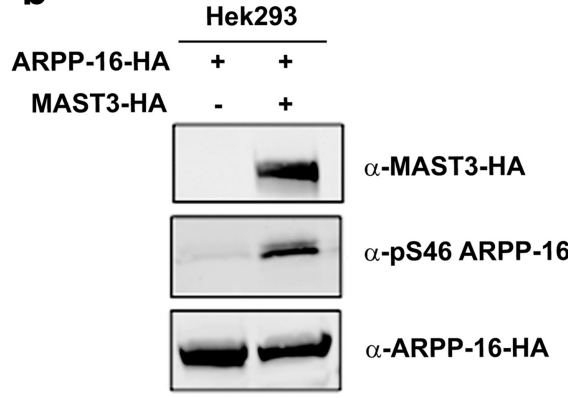

d

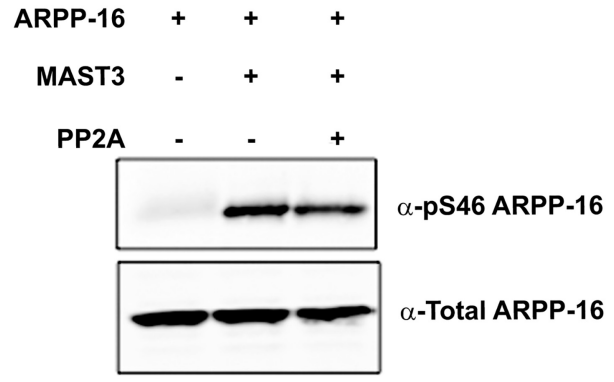

Figure 2. ARPP-16 is phosphorylated at Ser46 in intact cells and in vitro by MAST3 kinase. $\boldsymbol{a}$, Purified ARPP-16 was phosphorSer46 was measured by immunoblotting. Ser46 phosphorylation was normalized to total ARPP-16 levels, and to the zero time A-ARPP16 $(1 \mu \mathrm{M})$ was phosphorylated in vitro with MAST 3 kinase in the presence of thio- $\gamma$-ATP.P- $\gamma$-Ser-46-ARPP- 16 was then incubated without or with PP2A, and phosphorylation of Ser 46 was measured by immunoblotting.

atal tissue. These results therefore suggest that phospho-Ser46ARPP-16 would constitutively suppress PP2A activity in striatal neurons in vivo and that knock-out of ARPP-16 would possibly lead to increased dephosphorylation of PP2A substrates. Constitutive knock-out of ARPP-16/19 led to embryonic lethality in mice; therefore, conditional knock-out mice crossed to a mouse strain expressing Cre recombinase driven by the CaM kinase II $\alpha$ promoter were generated (ARPP-16/19 cKO). Immunoblotting confirmed that ARPP-16 was knocked out in forebrain regions (cortex, hippocampus, amygdala, and striatum) while expression of ENSA was not affected (Fig. $5 a$ ).

We examined the level of phosphorylation of selected PP2A substrates in ARPP-16/19 cKO mice. This included DARPP-32 at Thr75 (Nishi et al., 2000; Ahn et al., 2007a), Akt at Thr308 (Kuo et al., 2008), EF2 at Thr56 (Redpath and Proud, 1990; Redpath et al., 1993; Feschenko et al., 2002), and tau at Ser396 (Xu et al., 2008). The results obtained showed a significant decrease in the basal phosphorylation of DARPP-32 at Thr75 (Fig. $5 b ; t_{(6)}=$ 3.528, $p=0.012$ ) as well as Akt at Thr308 (Fig. $5 c ; t_{(6)}=2.744$, $p=0.034)$ in cKO mice compared with WT. In contrast, no difference in basal phosphorylation of EF2 at Thr56 or tau at Ser396 was detected (Fig. $6 a, b$ ).

The phosphorylation of Thr202 of ERK1, which is a target for PP2A (Sontag et al., 1993; Van Kanegan et al., 2005), was also analyzed. In this case, phosphorylation of ERK was examined in striatal slices from ARPP-16/19 cKO mice and WT controls incubated with forskolin (10 $\mu \mathrm{M}$ for $0,10,30$, or $60 \mathrm{~min})$. As expected (see, e.g., Grewal et al., 1999), forskolin stimulated 
a
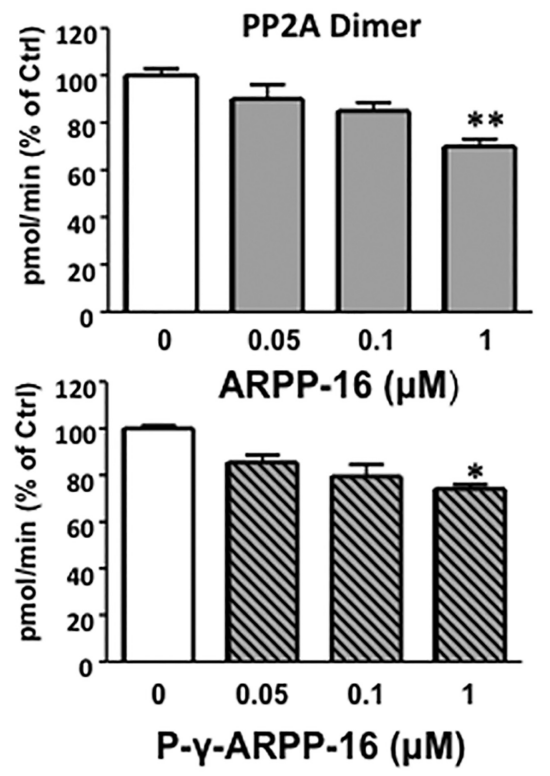

b
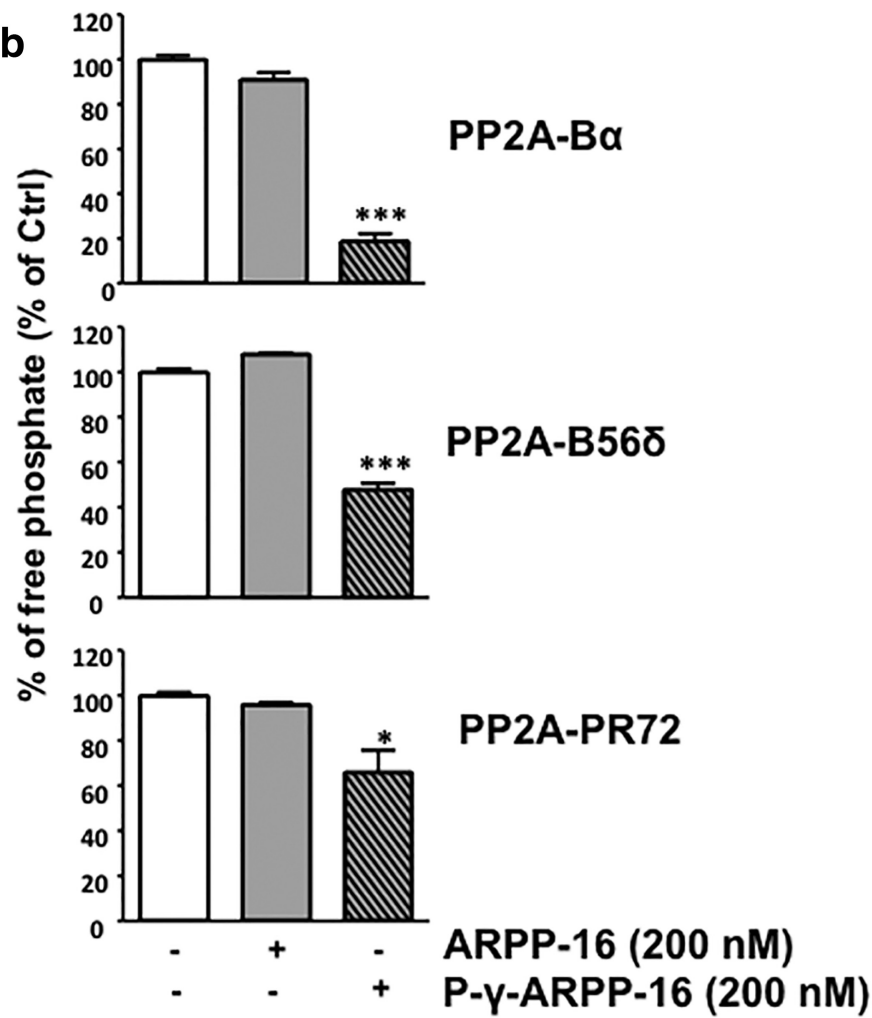

Figure 3. ARPP-16 inhibits PP2A activity in vitro. a, Purified PP2A-AC dimer ( $0.01 \mathrm{U} / \mu \mathrm{l}$, Millipore) was incubated with increasing concentration $(0,0.05,0.1$, and $1 \mu \mathrm{M})$ of recombinant, purified dephospho-ARPP-16 (top) or P- $\gamma$-Ser46-ARPP-16 (bottom) for $10 \mathrm{~min}$ at $37^{\circ} \mathrm{C}$ and phosphatase activity measured using $500 \mu \mathrm{m}$ phosphopeptide as substrate. Phosphate release was detected using a malachite green assay with absorbance measured at $650 \mathrm{~nm}$. $\boldsymbol{b}$, Recombinant Flag-B $\alpha$, Flag-B56 $\delta$, or Flag-PR72 subunits were individually overexpressed in HEK293 cells, and PP2A heterotrimers were isolated by immunoprecipitation with anti-Flag antibody. PP2A heterotrimeric forms were incubated with $200 \mathrm{~nm}$ dephospho-ARPP- 16 or P- $\gamma$-Ser $46-\mathrm{ARPP}-16$ for $10 \mathrm{~min}$ at $37^{\circ} \mathrm{C}$ with $\left[{ }^{32} \mathrm{P}\right]-$ T75-DARPP-32 as substrate. ${ }^{32} \mathrm{P}$ release was measured following TCA precipitation and scintillation counting. Results are all expressed as percentage changes with respect to PP2A alone (white bars). ${ }^{*} p<0.05$ (Newman-Keuls test). ${ }^{* *} p<0.01$ (Newman-Keuls test). ${ }^{* * *} p<0.001$ (Newman-Keuls test). Error bars indicate SEM.

a
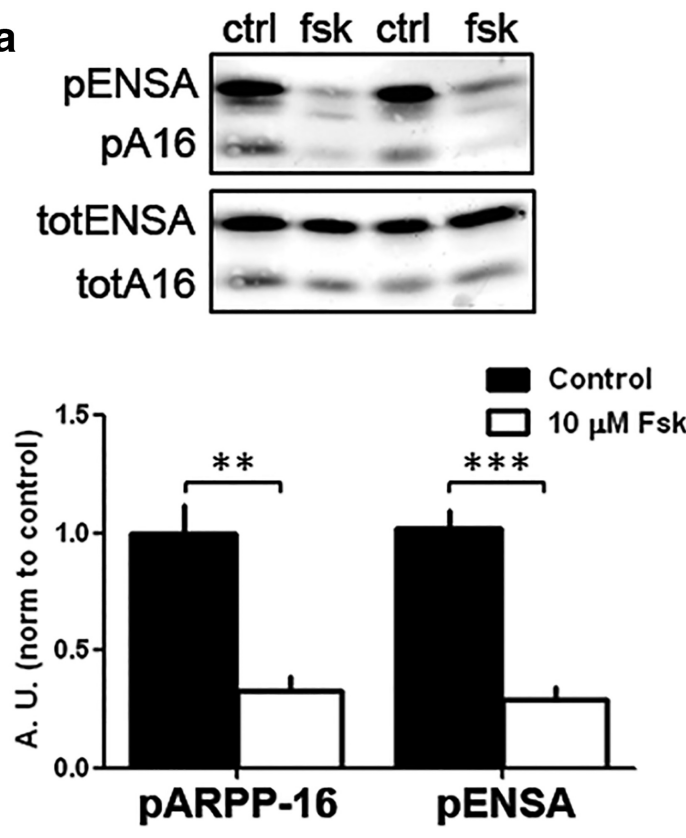

b
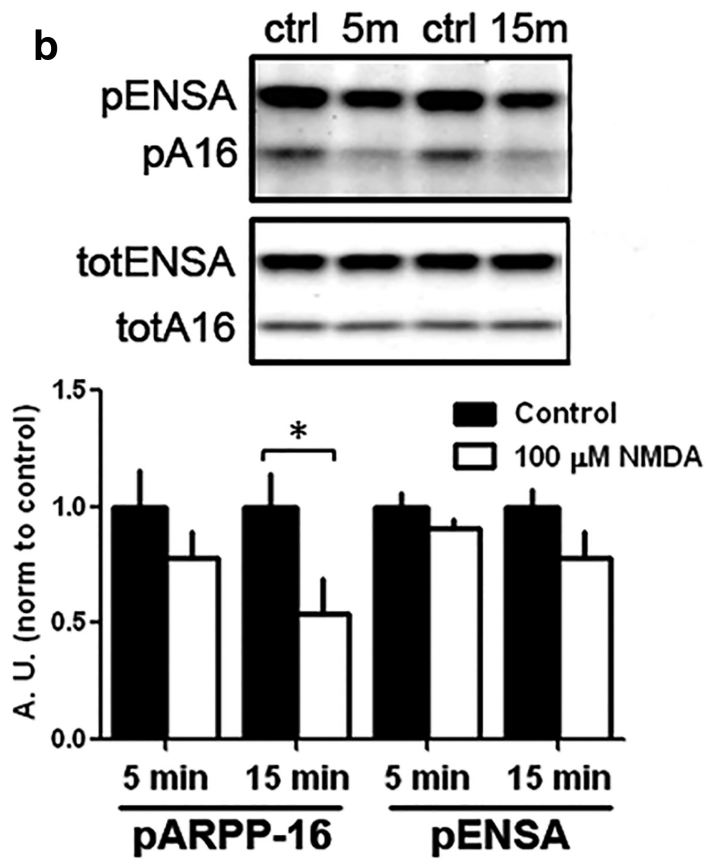

Figure 4. Regulation of phosphorylation of ARPP-16 at Ser46 and ARPP-19/ENSA at Ser62 in striatal slices. $\boldsymbol{a}$, Rat striatal slices ( $n=6$ per condition) were treated without (Control, ctrl) or with $10 \mu \mathrm{m}$ forskolin (fsk) for $10 \mathrm{~min}$. Samples (30 $\mu \mathrm{g}$ total lysate) were analyzed by immunoblotting for phospho-Ser46 and total ARPP-16 or phospho-Ser62 and total ENSA (top). Phospho-site signals were each normalized to total protein, and data for forskolin treatment were normalized to controls (bottom bar graph). ${ }^{* *} p<0.01$ (Student's $t$ test). ${ }^{* * *} p<0.001$ (Student's $t$ test). Error bars indicate SEM. $\boldsymbol{b}$, Striatal slices ( $n=3$ or 4 per condition) were treated without (ctrl) or with $100 \mu \mathrm{m}$ NMDA for 5 min ( $5 \mathrm{~m}$ ), or 15 min (15m), and differences in phosphorylation of ARPP- 16 at Ser46 and ENSA at Ser62 were analyzed as in $\boldsymbol{a} .{ }^{*} p<0.05$ (multivariate ANOVA with Bonferroni post hoc analysis). Error bars indicate SEM. 
a

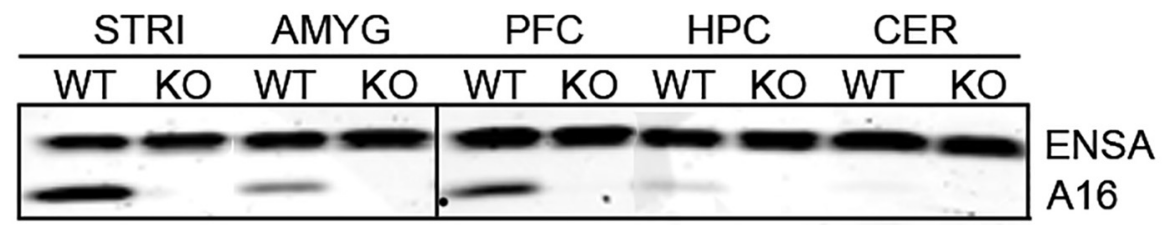

b

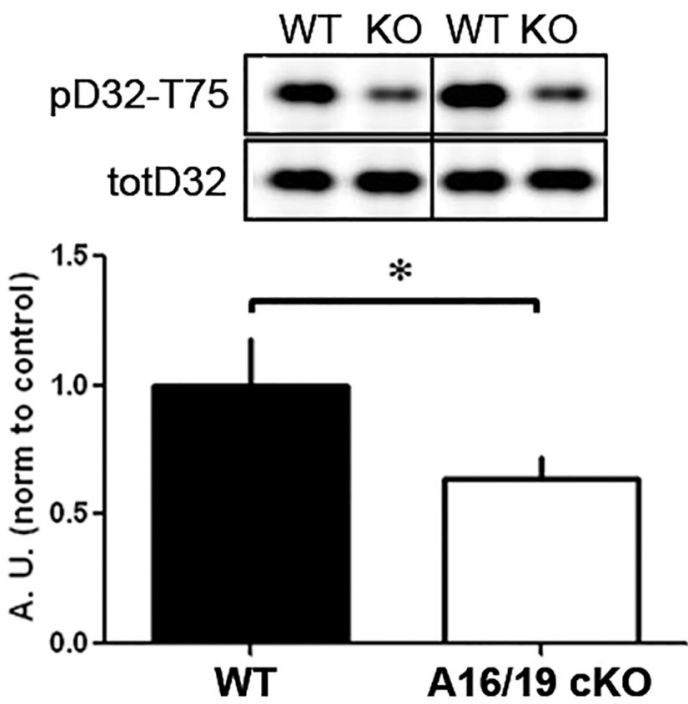

C
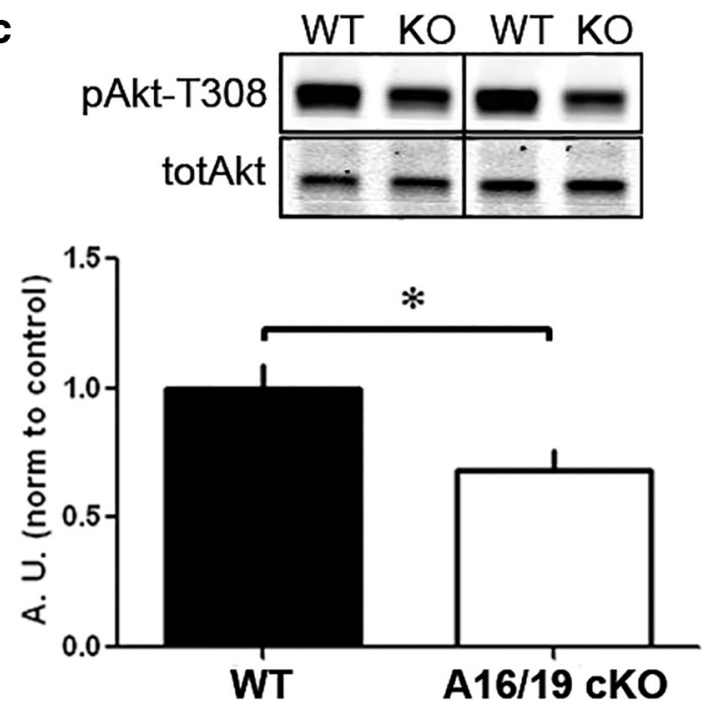

d

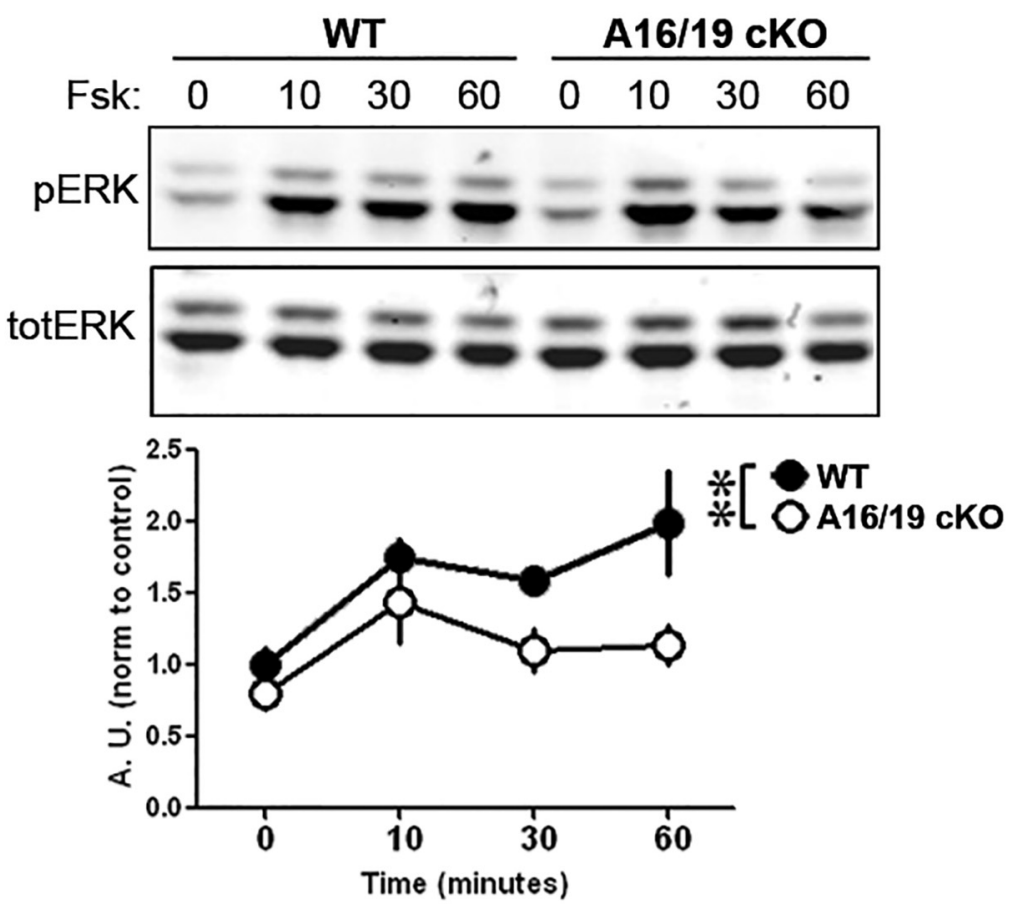

Figure 5. ARPP-16/19 regulates PP2A in a substrate-specific manner in striatum. $\boldsymbol{a}$, Samples from different brain regions (as indicated) from WT and conditional ARPP-16/19 knock-out (cK0) mice were analyzed by immunoblotting with an antibody that recognizes ARPP-16, ARPP-19, and ENSA. Striatal slices from ARPP-16/19 cKOs $(n=4)$ or WT littermate controls $(n=$ 3 or 4) were isolated and basal phosphorylation of the PP2A targets, (b) DARPP-32 at Thr75, or (c) Akt at Thr308 were analyzed by SDS-PAGE and immunoblotting. $\boldsymbol{b}$, Phospho-Thr75 (pD32-T75) and total DARPP-32 (totD32) blots. c, Phospho-Thr308 (pAkt-t308) and total Akt (totAkt) blots. Bottom bar graphs represent cumulative data. ${ }^{*} p<0.05$ (Student's $t$ test). Error bars indicate SEM. $\boldsymbol{d}$, Striatal slices from ARPP-16/19 cK0s $(n=4)$ or WT littermate controls $(n=4)$ were incubated with $10 \mu \mathrm{m}$ forskolin for $0,10,30$, or 60 min. Samples were analyzed by SDS-PAGE, and immunoblotting was done for phospho-Thr202/204 and total ERK1/2 (top); quantitation of phosphorylation as done for Thr202/204 normalized to ERK1. Bottom graph represents cumulative data. ${ }^{* *} p<0.01$ (multivariate ANOVA). $\boldsymbol{b}-\boldsymbol{d}$, Phospho-site signals were each normalized to total protein, and then data for cKO mouse samples were normalized to controls. 
a

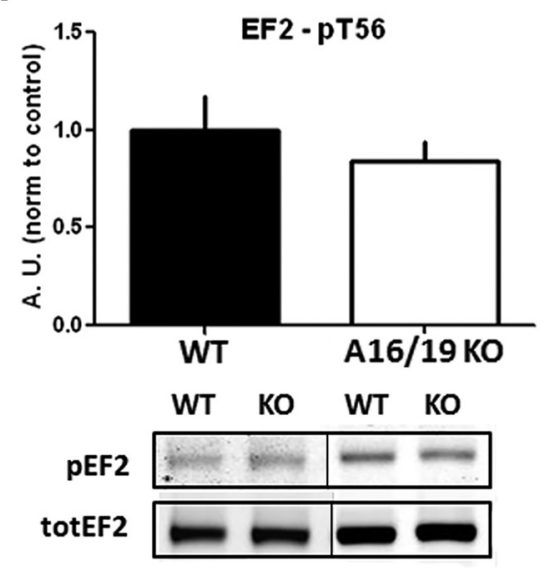

C

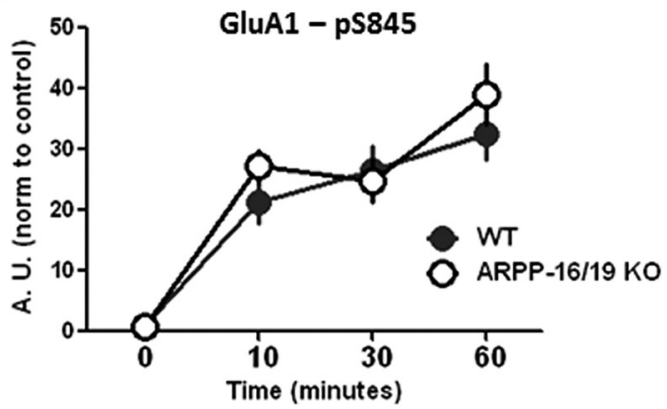

WT

Fsk: \begin{tabular}{llllllll}
\hline 0 & 10 & 30 & 60 & 0 & 10 & 30 & 60
\end{tabular}

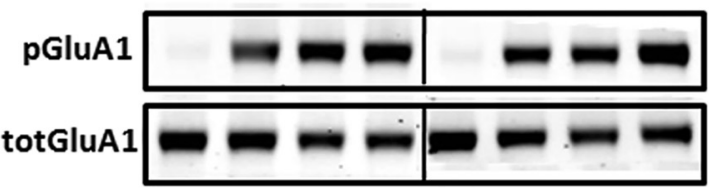

b

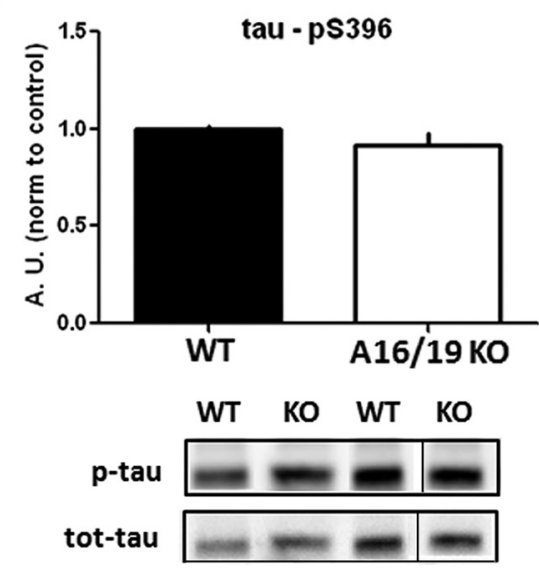

d

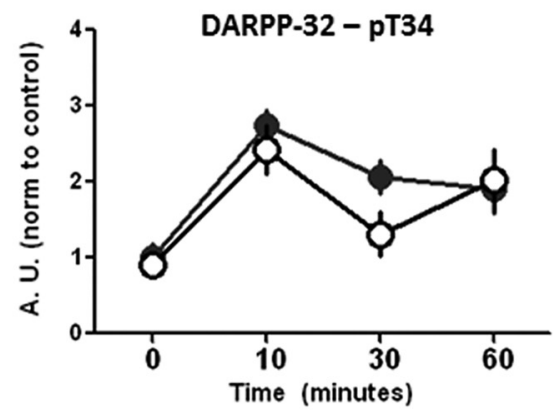

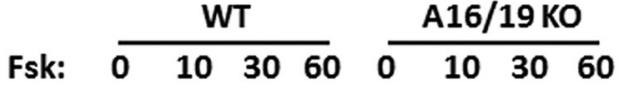

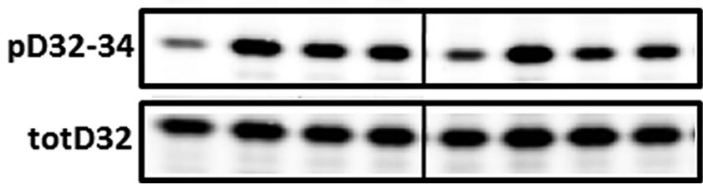

Figure 6. ARPP-16/19 does not regulate Ser845 phosphorylation of GluA1 or Thr34 phosphorylation of DARPP-32. Striatal slices from ARPP-16/19 cK0s ( $n=4$ ) or WT littermate controls ( $n=3$ or 4) were isolated and basal phosphorylation of the PP2A targets, (a) elongation factor-2 (EF2) at Thr56 or (b) tau at Ser396, were analyzed by immunoblotting. $\boldsymbol{a}$, Phospho-Thr56 (pEF2) and total EF2 (TotEF2) blots. $\boldsymbol{b}$, Phospho-Ser396 (pTau) and total tau (TotTau) blots. Bar graphs represent cumulative data (multivariate ANOVA $p>0.05$ ). Data for cK0 mouse samples were normalized to controls. Striatal slices from ARPP-16/19 cKOs $(n=4)$ or WT littermate controls $(n=4)$ were incubated with $10 \mu \mathrm{m}$ forskolin for $0,10,30$, or $60 \mathrm{~min}$. Samples were analyzed by immunoblotting for (c) phospho-Ser845 and total GluA1 and (d) phospho-Thr34 and total DARPP-32 (bottom); quantitation of phosphorylation was calculated for Ser845 or Thr34 normalized to total GluA1 or total DARPP-32, respectively. Graphs represents cumulative data (multivariate ANOVA, $p>0.05$ ). Data for cK0 mouse samples were normalized to controls.

phosphorylation of ERK1/2 in a time-dependent manner in striatal slices from WT mice, but this effect was attenuated in slices from ARPP-16/19 cKO mice (Fig. 5d; multivariate ANOVA, $\left.F_{(1,24)}=11.71, p=0.002\right)$. We interpret this result as indicating that there was no change in the kinase activity that phosphorylated ERK in response to forskolin in slices from WT and ARPP16/19 cKO mice, but greater PP2A activity in ARPP-16/19 cKO mice resulted in more rapid dephosphorylation of pERK, which was revealed at longer time points. Notably, substrates for either PP1 (the GluA1 subunit of AMPAR at Ser845) (Snyder et al., 2000) or calcineurin (DARPP-32 at Thr34) (King et al., 1984), showed no phosphorylation differences in ARPP-16/19 cKO mice following stimulation of striatal slices with forskolin (Fig. $6 c$ and Fig. 6d, respectively; GluA1-Ser845, multivariate ANOVA, $F_{(1,24)}=1.29, p=0.268$; DARPP-32-Thr34, multivariate ANOVA, $\left.F_{(1,24)}=1.91, p=0.180\right)$, suggesting that the effects observed are specific for PP2A.
Conditional ARPP-16/19 knock-out mice exhibit increased motivation and a decreased locomotor response to acute cocaine

Increased salience for rewards is a hallmark of psychomotor stimulant addiction (Robinson and Berridge, 2001; Cardinal and Everitt, 2004), and psychomotor stimulants are known to increase motivation to nose-poke for food reinforcement measured in a progressive ratio schedule (Poncelet et al., 1983). While ARPP-16/19 cKO mice showed no difference in acquiring an instrumental learning task compared with WT littermate controls (Fig. $7 a$; repeated-measures ANOVA, $F_{(1,19)}=1.30, p=$ 0.268 ), they exhibited a significantly higher breakpoint ratio on 2 consecutive days of progressive ratio assessment (Fig. 7b; repeated-measures ANOVA with Bonferroni post hoc analysis, $\left.F_{(1,18)}=6.35, p=0.021\right)$. Thus, ARPP-16/19 cKO mice exhibit increased motivation to respond for a food reinforcer compared with WT littermate controls. 
a

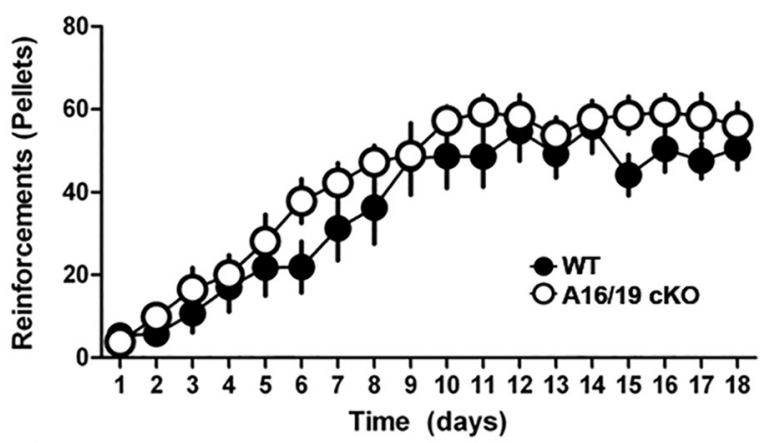

C

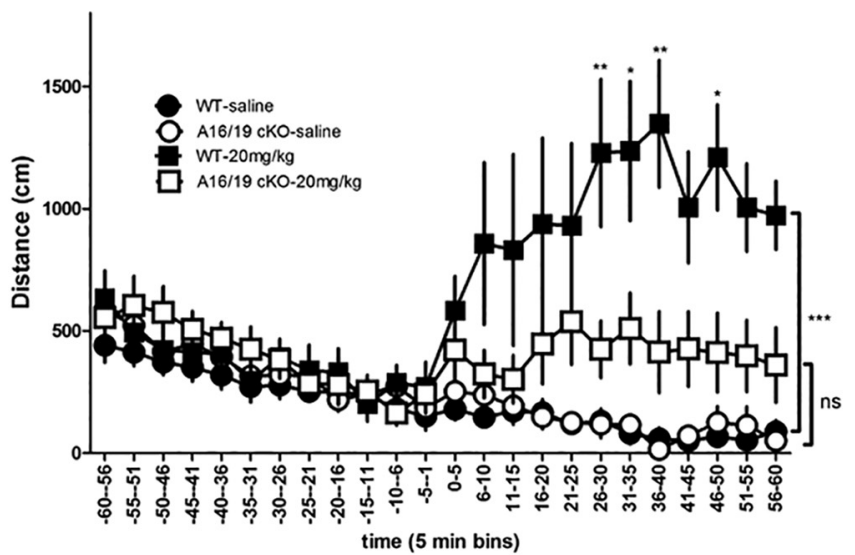

b

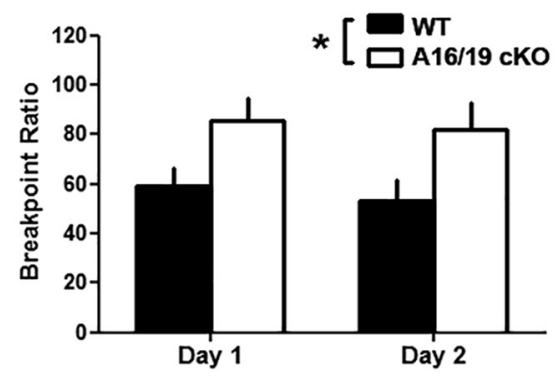

d

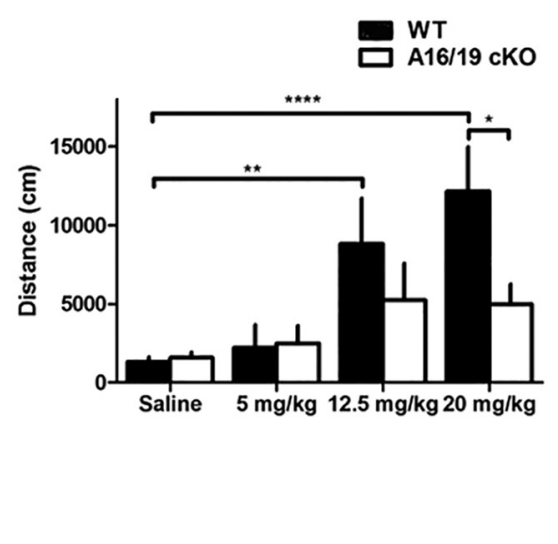

e

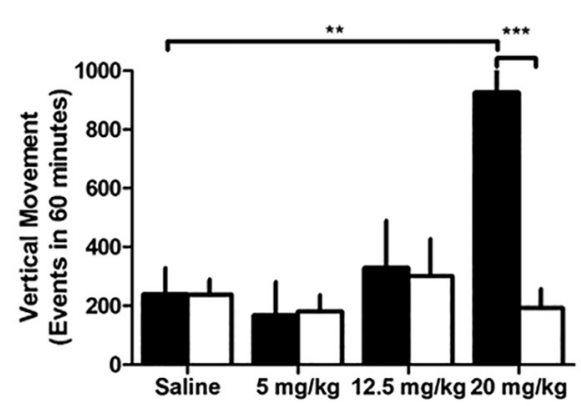

$\mathbf{f}$

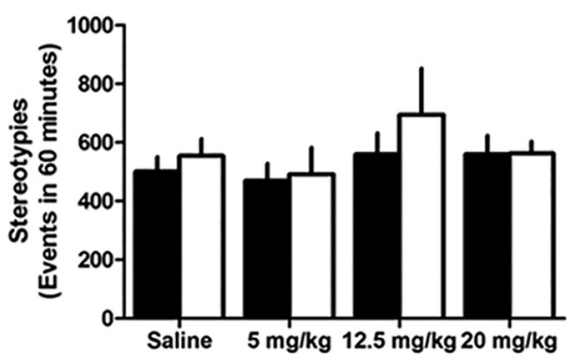

Figure 7. ARPP-16/19 cK0 mice show increased motivation in progressive ratio responding and an altered locomotor response to cocaine. $a$, ARPP-16/19 cK0s (open circles, $n=11$ ) and WT littermate controls (closed circles, $n=9$ ) were trained on a VR2 schedule of reinforcement to respond by nose-poking into an assigned nose aperture to receive a food reinforcer until stable acquisition of reward was measured. No significant difference in acquisition of this task was detected between the cKOs and WT controls (repeated-measures ANOVA). Data are mean \pm SEM. $\boldsymbol{b}, 0$. $n c e$ the WT (black bars) and ARPP-16/19 cKO (white bars) mice were stably trained, the number of responses required to receive a food reinforcer increased using an escalating schedule of reinforcement $(1,5,9 \ldots x+4$ responses/reinforcer). The breakpoint ratio was defined as the response/reinforcer ratio achieved by an animal when the animal gave up nose-poking (defined as 5 min of no activity in the active nose aperture). This paradigm was completed on 2 consecutive days. ${ }^{*} p<0.05$ (repeated-measures ANOVA with Bonferroni posthoc analysis). Data are mean \pm SEM. $c, d, A R P P-16 / 19$ cK0 and WT littermate controls were exposed to saline $(n=10 \mathrm{WT} ; n=11 \mathrm{cKO}), 5 \mathrm{mg} / \mathrm{kg}(n=10 \mathrm{WT} ; n=9 \mathrm{cKO}), 12.5 \mathrm{mg} / \mathrm{kg}(n=7 \mathrm{WT} ; n=6 \mathrm{cKO})$, or $20 \mathrm{mg} / \mathrm{kg}(n=8 \mathrm{WT}, n=10 \mathrm{cK} 0)$ cocaine (i.p.); then locomotor activity was measured using an Accuscan tracking system. c, Horizontal movement during the 60 min postinjection session were binned into 5 min increments. ARPP-16/19 cK0 (open circles and squares) shows an attenuated response to $20 \mathrm{mg} / \mathrm{kg}$ cocaine compared with WT littermate controls (closed circles and squares) and no significant effect of cocaine compared with cK0 animals exposed to saline. ${ }^{*} p<0.05$ (repeated-measures ANOVA with Bonferroni post hoc analysis). ${ }^{* *} p<0.01$ (repeated-measures ANOVA with Bonferroni post hoc analysis). ${ }^{* * *} p<0.001$ (repeated-measures ANOVA with Bonferroni post hoc analysis). Data are mean \pm SEM. $\boldsymbol{d}$, Total horizontal movement over the 60 min postinjection session for saline ( $n=9$ for both WT and cK0), $5 \mathrm{mg} / \mathrm{kg}(n=10 \mathrm{WT} ; n=9 \mathrm{CKO}), 12.5 \mathrm{mg} / \mathrm{kg}(n=7 \mathrm{WT} ; n=6 \mathrm{cK} 0)$, and $20 \mathrm{mg} / \mathrm{kg}(n=8 \mathrm{WT}, n=10 \mathrm{cK} 0)$ showed significant hyperlocomotor activity in WT animals following $12.5 \mathrm{mg} / \mathrm{kg}$ and $20 \mathrm{mg} / \mathrm{kg}$ cocaine exposure. ${ }^{* *} p<0.01$ (two-way ANOVA with Bonferroni post hoc analysis). ${ }^{* * *} p<0.0001$ (two-way ANOVA with Bonferroni post hoc analysis). Data are mean \pm SEM. There was no significant difference in total distance moved by cK0 mice in response to cocaine exposure compared with saline exposure, and ARPP-16/19 cK0 mice showed significantly less cocaine-induced locomotor activity over 60 min compared with WT controls at $20 \mathrm{mg} / \mathrm{kg}$ cocaine. ${ }^{*} p<0.05$ (two-way ANOVA with Bonferroni posthoc analysis). Data are mean \pm SEM. e, WT and ARPP-16/19 cK0 mice were exposed to saline or cocaine as described in $\boldsymbol{c}, \boldsymbol{d}$, and events of vertical movement were measured and summarized for $1 \mathrm{~h}$ after injection of cocaine or saline. WT control animals showed significantly increased vertical movement following $20 \mathrm{mg} / \mathrm{kg}$ cocaine injection compared with WT animals injected with saline. ${ }^{* * *} p<0.001$ (two-way ANOVA with Bonferroni posthoc analysis). Data are mean \pm SEM. ARPP-16/19 cK0 mice showed no difference in vertical movement at any dose. At $20 \mathrm{mg} / \mathrm{kg}$ cocaine, ARPP- $16 / 19$ cKO mice showed significantly reduced vertical movement compared with WT control animals. ${ }^{* *} p<0.01$ (two-way ANOVA with Bonferroni post hoc analysis). Data are mean \pm SEM. $f$, No significant differences were observed in stereotypic behavior in either ARPP-16/19 cKO mice or WT control animals at any dose. 

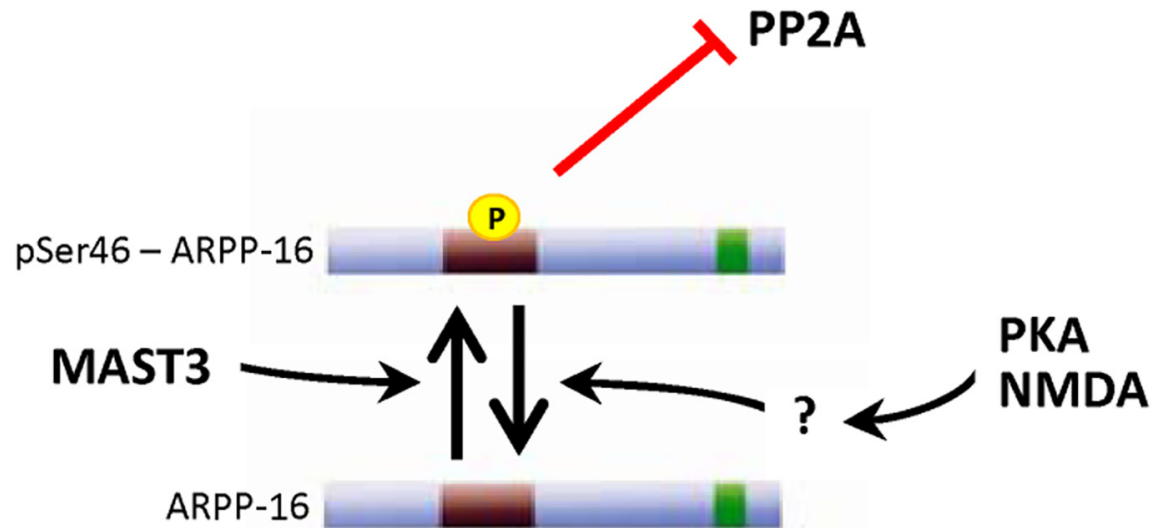

Figure 8. Schematic illustration of ARPP-16 regulation in striatal neurons. ARPP- 16 is phosphorylated by MAST3 at Ser 46 to a high basal stoichiometry in striatum, which leads to selective inhibition of PP2A activity. Dephosphorylation of Ser46 in ARPP-16 is increased by activation of PKA or by stimulation of NMDA receptors, leading to disinhibition of PP2A.

No difference was observed in baseline locomotor activities in ARPP-16/19 cKO mice and their WT littermate controls (Fig. 7c). ARPP-16/19 cKO mice and WT littermate controls were acutely exposed to saline or cocaine $(5,12.5$, or $20 \mathrm{mg} / \mathrm{kg}$ i.p.) after 60 min of habituation to the tracking chambers. Locomotor activity was then recorded for $60 \mathrm{~min}$ with distance traveled summarized for the session (Fig. 7d) (data for $20 \mathrm{mg} / \mathrm{kg}$ cocaine are also shown in 5 min bins in Fig. 7c). No differences were seen in ARPP-16/19 cKO mice and WT mice in response to a saline injection or 5 $\mathrm{mg} / \mathrm{kg}$ cocaine (Fig. $7 d$ ), whereas significant effects on locomotor activity were observed at $12.5 \mathrm{mg} / \mathrm{kg}$ in WT but not in ARPP16/19 cKO mice (Fig. 7d; two-way ANOVA with Bonferroni post hoc analysis, $F_{(1,31)}=12.41, p=0.0013$ for saline vs $12.5 \mathrm{mg} / \mathrm{kg}$ in WT mice). WT mice showed a significant increase in locomotor activity following $20 \mathrm{mg} / \mathrm{kg}$ cocaine injection compared with saline injected WT mice (Fig. 7d; two-way ANOVA with Bonferroni post hoc analysis, $\left.F_{(1,32)}=23.23, p<0.0001\right)$. A significant attenuation in cocaine-induced locomotor activity was observed in ARPP-16/19 cKO mice (Fig. 7d; two-way ANOVA with Bonferroni post hoc analysis, $\left.F_{(1,32)}=6.62, p=0.0149\right)$. When the 20 $\mathrm{mg} / \mathrm{kg}$ cocaine data were binned into $5 \mathrm{~min}$ intervals, WT mice exposed to $20 \mathrm{mg} / \mathrm{kg}$ cocaine showed significant hyperlocomotor activity (repeated-measures ANOVA with Bonferroni post hoc analysis, $\left.F_{(23,345)}=7.16, p<0.0001\right)$. However, ARPP-16/19 cKO mice exhibited significantly attenuated hyperlocomotor activity compared with WT controls and no significant effect of cocaine on locomotion compared with ARPP-16/19 cKO injected with saline (Fig. $7 c$; repeated-measures ANOVA with Bonferroni post hoc analysis, $F_{(1,16)}=4.97, p=0.0405$ for $\mathrm{cKO}$ and WT comparison; repeated-measures ANOVA with Bonferroni post hoc analysis, $F_{(1,17)}=2.67, p=0.1205$ for saline and 20 $\mathrm{mg} / \mathrm{kg}$ cocaine comparison of $\mathrm{KKO}$ mice).

Vertical movement was measured and summarized for $1 \mathrm{~h}$ after injection of cocaine or saline. WT control animals showed significantly increased vertical movement following $20 \mathrm{mg} / \mathrm{kg}$ cocaine injection compared with WT animals injected with saline (Fig. 7e; two-way ANOVA with Bonferroni post hoc analysis, $\left.F_{(1,35)}=7.30, p=0.0106\right)$, whereas ARPP-16/19 cKO showed no difference in vertical movement at any dose. At $20 \mathrm{mg} / \mathrm{kg}$ cocaine, ARPP-16/19 cKO showed significantly reduced vertical movement compared with WT control animals (Fig. 7e; two-way ANOVA with Bonferroni post hoc analysis, $F_{(1,35)}=9.58, p=$
0.0039). Importantly, no differences in stereotypies were observed at any dose of cocaine compared with saline in either ARPP-16/19 cKO mice or WT controls (Fig. $7 f$ ). Finally, to further address any baseline behavioral differences that may confound these results, several additional behavioral analyses were performed. No differences were seen between WT and ARPP-16/19 cKO mice in long-term memory expression, acquisition of cued fear conditioning, or open field testing for anxiety (data not shown). Given its very high expression in MSNs, the behavioral phenotypes likely involve knock-out in these striatal projection neurons. However, ARPP-16 is expressed in other brain regions and conditional knockout in other cell types could contribute to the behavioral phenotypes observed.

\section{Discussion}

The results obtained in this study identify ARPP-16 as an inhibitor of specific heterotrimeric forms of the serine-threonine phosphatase, PP2A (Fig. 8). Inhibition of PP2A is dependent on phosphorylation of ARPP-16 at Ser46 by MAST3 kinase, an enzyme that is highly expressed in striatum. Consistent with a high basal activity of MAST3, phosphorylation of Ser46 is very high, suggesting that phospho-Ser46-ARPP-16 acts normally to selectively suppress PP2A activity in striatum. In support of this, biochemical studies of ARPP-16 cKO mice indicate that the phosphorylation of a subset of specific striatal substrates for PP2A are increased and that this is associated with altered behavior in the ARPP-16/19 cKO mice. These results complement and extend recent studies that highlight critical roles for phosphorylation of the ARPP-16-related proteins, ARPP-19 and ENSA, by Gwl in the inhibition of PP2A during mitosis and meiosis (Gharbi-Ayachi et al., 2010; Mochida et al., 2010; Dupré et al., 2014). Strikingly, we show that, in striatal neurons, the ARPP-16/ PP2A regulatory system is regulated by MAST3 kinase in an opposing manner to that found in regulation of the cell cycle by ARPP-19/ENSA by Gwl.

Previous studies have suggested functions for the ARPP-16 homolog, ARPP-19, in GAP-43 mRNA stabilization (Irwin et al., 2002) and as a binding partner for $\alpha$-synuclein (Woods et al., 2007). ENSA was originally identified as being a potential extracellular ligand for the $\mathrm{K}_{\mathrm{ATP}}$-coupled sulfonylurea receptor (Virsolvy-Vergine et al., 1992). However, there is no evidence that ENSA is found extracellularly. Moreover, the ubiquitous distribution of ARPP-19 and ENSA would suggest a broader function than regulation of the neuronal GAP-43 mRNA or interactions with the neuronal protein, $\alpha$-synuclein. Indeed, the recent studies that have found that ARPP-19 or ENSA is required for the ability of the Gwl kinase to regulate PP2A during mitosis in frog oocytes, together with our results, suggest that the function of the ARPP-16/19/ENSA family of proteins is limited to control of PP2A activity.

Heterotrimeric forms of PP2A contain a catalytic C, a scaffolding $A$, and various $B$ subunits that influence the substrate specificity of the different PP2A isoforms (Janssens and Goris, 2001; Xing et al., 2006; Xu et al., 2006; Xu et al., 2008). Our studies indicated that ARPP-16 can bind directly to the A subunit but that the dephospho- or phospho-Ser46-forms of the protein have 
little effect on the activity of the isolated AC dimer. However, we find that phospho-Ser46-ARPP-16, but not dephospho-ARPP16 , can inhibit heterotrimeric forms of the enzyme, especially those containing either the $\mathrm{B} \alpha$ or $\mathrm{B} 56 \delta$ subunits. ARPP- 16 interacts with HEAT repeats 3-7 of the A subunit, the same general region that binds both $B$ subunits and ST. Given that only the heterotrimeric forms of the enzyme are inhibited by phosphoSer46-ARPP-16, this would suggest that, although ARPP-16 can bind directly to the A subunit, it does not compete for binding with the B subunit. Moreover, given the variable effect on different heterotrimeric forms of $\mathrm{PP} 2 \mathrm{~A}$, there presumably must be specific interactions between phospho-ARPP-16 and some, but not all, B subunits that combine to inhibit substrate interaction. Recent studies of Gwl-mediated inhibition of PP2A in frog oocytes suggested that the $\mathrm{B} \alpha$ isoform form of PP2A might be selectively regulated (Castilho et al., 2009; Mochida et al., 2010). However, our results suggest that, in striatal neurons, the B56 $\delta$ form of PP2A may also be subject to regulation by ARPP-16. Thus, the efficacy and selectivity of phospho-ARPP-16 (or ARPP-19 or ENSA) are likely influenced by the nature of phospho-protein substrate used in combination with a specific $B$ subunit isoform.

We identified MAST3 kinase as being involved in regulation of ARPP-16 in striatum from the studies of the Gwl kinase and ARPP-19 and ENSA in frog oocytes (Gharbi-Ayachi et al., 2010; Mochida et al., 2010). The MASTL kinase has greatest similarity to Gwl and is likely functionally equivalent to Gwl in dividing mammalian cells (Voets and Wolthuis, 2010). There are four MAST kinases, all of which are expressed in brain, with MAST3 kinase being selectively found in striatum (Garland et al., 2008). Based on our biochemical studies that indicate MAST3 efficiently phosphorylates Ser46 of ARPP-16, and that MAST3, but not other related MAST kinase isoforms, is highly expressed in striatum, it is likely that MAST3 is responsible for regulation of ARPP-16 in situ.

Phosphorylation of Ser88 of ARPP-16 does not influence PP2A activity (V. Musante, A.C. Nairn, unpublished results), raising the question of how this might contribute to ARPP-16 function. Our studies indicate that Ser46 is phosphorylated basally to a high stoichiometry in striatum. Treatment of striatal slices with forskolin led to a substantial dephosphorylation at Ser46 of ARPP-16 (and also Ser62 of ENSA). These results suggest that rather than regulate ARPP-16 activity directly, cAMPdependent signaling serves to attenuate phosphorylation of Ser46 leading to disinhibition of PP2A (Fig. 8). It is possible that phosphorylation of ARPP-16 acts in an intramolecular fashion to inhibit Ser46 phosphorylation by MAST3 or to increase the dephosphorylation of this site. Alternatively, MAST3 kinase may be suppressed by cAMP signaling, or the activity of a phosphatase could be increased. With respect to the latter situation, PKAmediated activation of the B56 $\delta$ form of PP2A (Ahn et al., 2007a) could be involved. Dephosphorylation of Ser46 of ARPP-16 was also regulated by NMDA receptor activation in striatal slices, indicating that ARPP-16 is controlled by multiple signaling pathways.

In support of the hypothesis that phospho-Ser46-ARPP-16 acts to basally inhibit selected PP2A heterotrimeric isoforms, we found that conditional knock-out of ARPP-16/19 led to decreased phosphorylation of a subset of PP2A substrates. ARPP-16 is important for the PP2A-dependent regulation of DARPP-32, Akt, and ERK, although it does not affect tau and EF2. Additionally, calcineurin regulation of DARPP-32 and PP1 regulation of GluA1 are not affected in ARPP-16/19 cKO mice. It is likely that the selective effect of ARPP-16 knock-out on phosphorylation of PP2A targets is linked to the ability of ARPP-16/19 to regulate specific B subunits while leaving others unaffected. However, although dephosphorylation of DARPP-32 by PP2A involves both $\mathrm{B} 56 \delta$ (or $\mathrm{B}^{\prime} \delta$ ) and PR72/B", it is not known whether $\mathrm{B} \alpha$ confers any specificity for DARPP-32 (Ahn et al., 2007a, b). Dephosphorylation of tau by PP2A appears to be dependent on $\mathrm{B} \alpha$, but not B' $\gamma$ (Sontag et al., 2004; Xu et al., 2008). However, dephosphorylation of Akt or ERK by PP2A exhibits dependence on both $\mathrm{B} \alpha$ and $\mathrm{B} 56$ subunits that is variable in different cell types (Van Kanegan et al., 2005; Letourneux et al., 2006; Rocher et al., 2007; Kuo et al., 2008; Rodgers et al., 2011). It is possible, therefore, that the relative expression levels of these different $\mathrm{B}$ subunits in MSNs may be important in terms of the forms of PP2A that are targeted by ARPP-16. In this regard, B56 $\delta$ is known to be highly expressed in striatal neurons (Ahn et al., 2007a; Louis et al., 2011).

Consistent with its high expression in MSNs, ARPP-16 is involved in regulation of behaviors associated with striatal function. Thus, conditional knock-out of this selective PP2A inhibitor enhanced motivation for food measured by progressive ratio responding yet attenuated locomotor response to acute cocaine injection. The motivational effects of ARPP-16/19 knock-out are opposite to that of genetic manipulation of the two other PKA substrates enriched in MSNs, namely, DARPP-32 and RCS. DARPP-32 S97A mutant mice show reduced motivation for a food reinforcement (Stipanovich et al., 2008) as did RCS knockout mice (Davis et al., 2012). However, DARPP-32 S97A mutant mice also show reduced preference for cocaine, as well as reduced cocaine sensitization, although direct studies of psychostimulant action in RCS knock-out mice have yet to be performed. These various behavioral consequences of genetic manipulation of DARPP-32, RCS, and ARPP-16 therefore suggest specific functions in the striatum that likely reflect their ability to regulate the actions of different serine/threonine phosphatases and/or reflect the different signaling pathways that regulate their activities.

The regulation of PP2A by ARPP-16 in striatum adds to our previous studies that have found that DARPP-32 and RCS control the actions of $\mathrm{PP} 1$ and calcineurin (PP2B), respectively. Notably, these three small, intrinsically disordered, PKA substrates collectively control the activities of three of the four major classes of serine/threonine protein phosphatases in striatal neurons, albeit by different mechanisms. Phosphorylation of DARPP-32 by PKA generates a pseudosubstrate inhibitor of PP1, whereas phosphorylation of RCS by PKA acts indirectly to inhibit PP2B. In contrast, ARPP-16 acts basally to inhibit PP2A, and this activity is likely relieved by suppression of MAST3 phosphorylation of ARPP-16 by cAMP signaling. The coevolution of an enrichment of regulators of serine/ threonine protein phosphatases in MSNs is striking and is presumably a reflection of the temporal and possibly spatial requirements for intracellular signaling responding to dopamine and other neurotransmitter inputs that coordinate with dopamine action in striatal MSNs. Several important questions remain to be answered. ENSA is expressed in similar levels as ARPP-16 in striatum and presumably may have complimentary or distinct biochemical and behavioral roles. Elucidation of the mechanistic details of the interaction between the phosphorylation of ARPP16/ENSA by PKA and MAST3 will also be needed to fully understand the functional role of regulation of PP2A by dopamine and other neurotransmitters in striatal neurons. 


\section{References}

Ahn JH, McAvoy T, Rakhilin SV, Nishi A, Greengard P, Nairn AC (2007a) Protein kinase A activates protein phosphatase $2 \mathrm{~A}$ by phosphorylation of the B568 subunit. Proc Natl Acad Sci U S A 104:2979-2984. CrossRef Medline

Ahn JH, Sung JY, McAvoy T, Nishi A, Janssens V, Goris J, Greengard P, Nairn AC (2007b) The B"/PR72 subunit mediates $\mathrm{Ca}^{2+}$-dependent dephosphorylation of DARPP-32 by protein phosphatase 2A. Proc Natl Acad Sci U S A 104:9876-9881. CrossRef Medline

Brené S, Lindefors N, Ehrlich M, Taubes T, Horiuchi A, Kopp J, Hall H, Sedvall G, Greengard P, Persson H (1994) Expression of mRNAs encoding ARPP-16/19, ARPP-21, and DARPP-32 in human brain tissue. J Neurosci 14:985-998. Medline

Cardinal RN, Everitt BJ (2004) Neural and psychological mechanisms underlying appetitive learning: links to drug addiction. Curr Opin Neurobiol 14:156-162. CrossRef Medline

Casanova E, Fehsenfeld S, Mantamadiotis T, Lemberger T, Greiner E, Stewart AF, Schütz G (2001) A CamKIIalpha iCre BAC allows brain-specific gene inactivation. Genesis 31:37-42. CrossRef Medline

Castilho PV, Williams BC, Mochida S, Zhao Y, Goldberg ML (2009) The M phase kinase Greatwall $(\mathrm{Gwl})$ promotes inactivation of PP2A/B55 $\delta$, a phosphatase directed against CDK phosphosites. Mol Biol Cell 20:47774789. CrossRef Medline

Chen Y, Xu Y, Bao Q, Xing Y, Li Z, Lin Z, Stock JB, Jeffrey PD, Shi Y (2007) Structural and biochemical insights into the regulation of protein phosphatase $2 \mathrm{~A}$ by small $\mathrm{t}$ antigen of SV40. Nat Struct Mol Biol 14:527-534. CrossRef Medline

Cho US, Xu W (2007) Crystal structure of a protein phosphatase 2A heterotrimeric holoenzyme. Nature 445:53-57. CrossRef Medline

Cho US, Morrone S, Sablina AA, Arroyo JD, Hahn WC, Xu W (2007) Structural basis of PP2A inhibition by small $\mathrm{t}$ antigen. PLoS Biol 5:e202. CrossRef Medline

Czernik AJ, Girault JA, Nairn AC, Chen J, Snyder G, Kebabian J, Greengard P (1991) Production of phosphorylation state-specific antibodies. Methods Enzymol 201:264-283. CrossRef Medline

Davis MM, Olausson P, Greengard P, Taylor JR, Nairn AC (2012) Regulator of calmodulin signaling knockout mice display anxiety-like behavior and motivational deficits. Eur J Neurosci 35:300-308. CrossRef Medline

Dulubova I, Horiuchi A, Snyder GL, Girault JA, Czernik AJ, Shao L, Ramabhadran R, Greengard P, Nairn AC (2001) ARPP-16/ARPP-19: a highly conserved family of cAMP-regulated phosphoproteins. J Neurochem 77: 229-238. CrossRef Medline

Dupré A, Daldello EM, Nairn AC, Jessus C, Haccard O (2014) Phosphorylation of ARPP19 by protein kinase A prevents meiosis resumption in Xenopus oocytes. Nat Commun 5:3318. CrossRef Medline

Feschenko MS, Stevenson E, Nairn AC, Sweadner KJ (2002) A novel cAMPstimulated pathway in protein phosphatase $2 \mathrm{~A}$ activation. J Pharmacol Exp Ther 302:111-118. CrossRef Medline

Garland P, Quraishe S, French P, O'Connor V (2008) Expression of the MAST family of serine/threonine kinases. Brain Res 1195:12-19. CrossRef Medline

Gharbi-Ayachi A, Labbé JC, Burgess A, Vigneron S, Strub JM, Brioudes E, Van-Dorsselaer A, Castro A, Lorca T (2010) The substrate of Greatwall kinase, Arpp19, controls mitosis by inhibiting protein phosphatase 2A. Science 330:1673-1677. CrossRef Medline

Girault JA, Horiuchi A, Gustafson EL, Rosen NL, Greengard P (1990) Differential expression of ARPP-16 and ARPP-19, two highly related cAMPregulated phosphoproteins, one of which is specifically associated with dopamine-innervated brain regions. J Neurosci 10:1124-1133. Medline

Gourley SL, Kiraly DD, Howell JL, Olausson P, Taylor JR (2008) Acute hippocampal brain-derived neurotrophic factor restores motivational and forced swim performance after corticosterone. Biol Psychiatry 64:884890. CrossRef Medline

Greengard P, Allen PB, Nairn AC (1999) Beyond the dopamine receptor: the DARPP-32/protein phosphatase-1 cascade. Neuron 23:435-447. CrossRef Medline

Grewal SS, York RD, Stork PJ (1999) Extracellular-signal-regulated kinase signalling in neurons. Curr Opin Neurobiol 9:544-553. CrossRef Medline

Hemmings HC Jr, Greengard P (1989) ARPP-21, a cyclic AMP-regulated phosphoprotein enriched in dopamine-innervated brain regions: I. Puri- fication and characterization of the protein from bovine caudate nucleus. J Neurosci 9:851-864. Medline

Hemmings HC Jr, Greengard P, Tung HY, Cohen P (1984a) DARPP-32, a dopamine-regulated neuronal phosphoprotein, is a potent inhibitor of protein phosphatase-1. Nature 310:503-505. CrossRef Medline

Hemmings HC Jr, Nairn AC, Aswad DW, Greengard P (1984b) DARPP-32, a dopamine- and adenosine $3^{\prime}: 5^{\prime}$-monophosphate-regulated phosphoprotein enriched in dopamine-innervated brain regions: II. Purification and characterization of the phosphoprotein from bovine caudate nucleus. J Neurosci 4:99-110. Medline

Horiuchi A, Williams KR, Kurihara T, Nairn AC, Greengard P (1990) Purification and CDNA cloning of ARPP-16, a cAMP-regulated phosphoprotein enriched in basal ganglia, and of a related phosphoprotein, ARPP-19. J Biol Chem 265:9476-9484. Medline

Irwin N, Chao S, Goritchenko L, Horiuchi A, Greengard P, Nairn AC, Benowitz LI (2002) Nerve growth factor controls GAP-43 mRNA stability via the phosphoprotein ARPP-19. Proc Natl Acad Sci U S A 99:1242712431. CrossRef Medline

Janssens V, Goris J (2001) Protein phosphatase 2A: a highly regulated family of serine/threonine phosphatases implicated in cell growth and signalling. Biochem J 353:417-439. CrossRef Medline

King MM, Huang CY, Chock PB, Nairn AC, Hemmings HC Jr, Chan KF, Greengard P (1984) Mammalian brain phosphoproteins as substrates for calcineurin. J Biol Chem 259:8080-8083. Medline

Kuo YC, Huang KY, Yang CH, Yang YS, Lee WY, Chiang CW (2008) Regulation of phosphorylation of Thr-308 of Akt, cell proliferation, and survival by the B55alpha regulatory subunit targeting of the protein phosphatase 2A holoenzyme to Akt. J Biol Chem 283:1882-1892. CrossRef Medline

Letourneux C, Rocher G, Porteu F (2006) B56-containing PP2A dephosphorylate ERK and their activity is controlled by the early gene IEX-1 and ERK. EMBO J 25:727-738. CrossRef Medline

Louis JV, Martens E, Borghgraef P, Lambrecht C, Sents W, Longin S, Zwaenepoel K, Pijnenborg R, Landrieu I, Lippens G, Ledermann B, Götz J, Van Leuven F, Goris J, Janssens V (2011) Mice lacking phosphatase PP2A subunit $\mathrm{PR} 61 / \mathrm{B}^{\prime} \delta$ (Ppp2r5d) develop spatially restricted tauopathy by deregulation of CDK5 and GSK3beta. Proc Natl Acad Sci U S A 108:69576962. CrossRef Medline

Marin P, Nastiuk KL, Daniel N, Girault JA, Czernik AJ, Glowinski J, Nairn AC, Prémont J (1997) Glutamate-dependent phosphorylation of elongation factor-2 and inhibition of protein synthesis in neurons. J Neurosci 17:3445-3454. Medline

McAvoy T, Nairn AC (2010) Serine/threonine protein phosphatase assays. Curr Protoc Mol Biol Chapter 18:Unit18. CrossRef Medline

McAvoy T, Zhou MM, Greengard P, Nairn AC (2009) Phosphorylation of Rap1GAP, a striatally enriched protein, by protein kinase A controls Rap1 activity and dendritic spine morphology. Proc Natl Acad Sci U S A 106: 3531-3536. CrossRef Medline

Mochida S, Maslen SL, Skehel M, Hunt T (2010) Greatwall phosphorylates an inhibitor of protein phosphatase $2 \mathrm{~A}$ that is essential for mitosis. Science 330:1670-1673. CrossRef Medline

Nairn AC, Detre JA, Casnellie JE, Greengard P (1982) Serum antibodies that distinguish between the phospho- and dephospho-forms of a phosphoprotein. Nature 299:734-736. CrossRef Medline

Nishi A, Snyder GL, Greengard P (1997) Bidirectional regulation of DARPP-32 phosphorylation by dopamine. J Neurosci 17:8147-8155. Medline

Nishi A, Bibb JA, Snyder GL, Higashi H, Nairn AC, Greengard P (2000) Amplification of dopaminergic signaling by a positive feedback loop. Proc Natl Acad Sci U S A 97:12840-12845. CrossRef Medline

Ouimet CC, Miller PE, Hemmings HC Jr, Walaas SI, Greengard P (1984) DARPP-32, a dopamine- and adenosine $3^{\prime}: 5^{\prime}$-monophosphate-regulated phosphoprotein enriched in dopamine-innervated brain regions: III. Immunocytochemical localization. J Neurosci 4:111-124. Medline

Ouimet CC, Hemmings HC Jr, Greengard P (1989) ARPP-21, a cyclic AMPregulated phosphoprotein enriched in dopamine-innervated brain regions: II. Immunocytochemical localization in rat brain. J Neurosci 9:865-875. Medline

Poncelet M, Chermat R, Soubrie P, Simon P (1983) The progressive ratio schedule as a model for studying the psychomotor stimulant activity of drugs in the rat. Psychopharmacology (Berl) 80:184-189. CrossRef Medline 
Rakhilin SV, Olson PA, Nishi A, Starkova NN, Fienberg AA, Nairn AC, Surmeier DJ, Greengard P (2004) A network of control mediated by regulator of calcium/calmodulin-dependent signaling. Science 306:698-701. CrossRef Medline

Redpath NT, Proud CG (1990) Activity of protein phosphatases against initiation factor-2 and elongation factor-2. Biochem J 272:175-180. CrossRef Medline

Redpath NT, Price NT, Severinov KV, Proud CG (1993) Regulation of elongation factor-2 by multisite phosphorylation. Eur J Biochem 213:689699. CrossRef Medline

Robinson TE, Berridge KC (2001) Incentive-sensitization and addiction. Addiction 96:103-114. CrossRef Medline

Rocher G, Letourneux C, Lenormand P, Porteu F (2007) Inhibition of B56containing protein phosphatase 2 As by the early response gene IEX-1 leads to control of Akt activity. J Biol Chem 282:5468-5477. CrossRef Medline

Rodgers JT, Vogel RO, Puigserver P (2011) Clk2 and B56beta mediate insulin-regulated assembly of the PP2A phosphatase holoenzyme complex on Akt. Mol Cell 41:471-479. CrossRef Medline

Snyder GL, Allen PB, Fienberg AA, Valle CG, Huganir RL, Nairn AC, Greengard P (2000) Regulation of phosphorylation of the GluR1 AMPA receptor in the neostriatum by dopamine and psychostimulants in vivo. J Neurosci 20:4480-4488. Medline

Sontag E, Fedorov S, Kamibayashi C, Robbins D, Cobb M, Mumby M (1993) The interaction of SV40 small tumor antigen with protein phosphatase $2 \mathrm{~A}$ stimulates the map kinase pathway and induces cell proliferation. Cell 75:887-897. CrossRef Medline

Sontag E, Luangpirom A, Hladik C, Mudrak I, Ogris E, Speciale S, White CL 3rd (2004) Altered expression levels of the protein phosphatase 2A $\mathrm{AB} \alpha \mathrm{C}$ enzyme are associated with Alzheimer disease pathology. J Neuropathol Exp Neurol 63:287-301. CrossRef Medline

Stipanovich A, Valjent E, Matamales M, Nishi A, Ahn JH, Maroteaux M, Bertran-Gonzalez J, Brami-Cherrier K, Enslen H, Corbillé AG, Filhol O, Nairn AC, Greengard P, Hervé D, Girault JA (2008) A phosphatase cascade by which rewarding stimuli control nucleosomal response. Nature 453:879-884. CrossRef Medline

Strack S, Zaucha JA, Ebner FF, Colbran RJ, Wadzinski BE (1998) Brain protein phosphatase $2 \mathrm{~A}$ : developmental regulation and distinct cellular and subcellular localization by B subunits. J Comp Neurol 392:515-527. CrossRef Medline

Van Kanegan MJ, Adams DG, Wadzinski BE, Strack S (2005) Distinct protein phosphatase $2 \mathrm{~A}$ heterotrimers modulate growth factor signaling to extracellular signal-regulated kinases and Akt. J Biol Chem 280:3602936036. CrossRef Medline

Virsolvy-Vergine A, Leray H, Kuroki S, Lupo B, Dufour M, Bataille D (1992) Endosulfine, an endogenous peptidic ligand for the sulfonylurea receptor: purification and partial characterization from ovine brain. Proc Natl Acad Sci U S A 89:6629-6633. CrossRef Medline

Voets E, Wolthuis RM (2010) MASTL is the human orthologue of Greatwall kinase that facilitates mitotic entry, anaphase and cytokinesis. Cell Cycle 9:3591-3601. CrossRef Medline

Walaas SI, Aswad DW, Greengard P (1983a) A dopamine- and cyclic AMPregulated phosphoprotein enriched in dopamine-innervated brain regions. Nature 301:69-71. CrossRef Medline

Walaas SI, Nairn AC, Greengard P (1983b) Regional distribution of calcium- and cyclic adenosine $3^{\prime}: 5^{\prime}$-monophosphate-regulated protein phosphorylation systems in mammalian brain: II. Soluble systems. J Neurosci 3:302-311. Medline

Walaas SI, Hemmings HC Jr, Greengard P, Nairn AC (2011) Beyond the dopamine receptor: regulation and roles of serine/threonine protein phosphatases. Front Neuroanat 5:50. CrossRef Medline

Woods WS, Boettcher JM, Zhou DH, Kloepper KD, Hartman KL, Ladror DT, Qi Z, Rienstra CM, George JM (2007) Conformation-specific binding of $\alpha$-synuclein to novel protein partners detected by phage display and NMR spectroscopy. J Biol Chem 282:34555-34567. CrossRef Medline

Xing Y, Xu Y, Chen Y, Jeffrey PD, Chao Y, Lin Z, Li Z, Strack S, Stock JB, Shi $Y$ (2006) Structure of protein phosphatase 2A core enzyme bound to tumor-inducing toxins. Cell 127:341-353. CrossRef Medline

Xu Y, Xing Y, Chen Y, Chao Y, Lin Z, Fan E, Yu JW, Strack S, Jeffrey PD, Shi Y (2006) Structure of the protein phosphatase 2A holoenzyme. Cell 127: 1239-1251. CrossRef Medline

Xu Y, Chen Y, Zhang P, Jeffrey PD, Shi Y (2008) Structure of a protein phosphatase 2A holoenzyme: insights into B55-mediated tau dephosphorylation. Mol Cell 31:873-885. CrossRef Medline

Yger M, Girault JA (2011) DARPP-32, jack of all trades: master of which? Front Behav Neurosci 5:56. CrossRef Medline 